\title{
A Review of the Genera Erythrococca and Micrococca.
}

\author{
BY \\ D. PRAIN, C.I.E., F.R.S. \\ Director of the Royal Gardens, Kew.
}

INTRODUCTORY.

T N a paper 'Sur le Mercurialis alternifolia, Desr., et sur les limites du 1 genre Mercurialis' (Adansonia, iii. I67-76) Baillon, in 1862, essayed to prove that Lamarck's treatment of this plant, ${ }^{1}$ on which Bentham based the genus Micrococca (Hook., Niger Flor., 5०3), is valid, and that, as a consequence, the genera Adenocline, Turcz. (Bull. Soc. Imp. Nat. Mosc. I843, 59), Seidelia, Baill. (Étud. gén. Euphorb.,465,t. 9), Claoxylon, A. Juss. (Tent. Gen. Euphorb., 43, t. I4) and Erythrococca, Benth. (Hook., Niger Flor., 506) are also referable to Mercurialis. These Euphorbiaceous types undoubtedly belong to a definite natural group, and our instinctive reluctance, even when the necessity is more obvious than in this case, to include in one genus annual herbs like Micrococca, Adenocline, Seidelia, and shrubs or trees like Claoxylon and Erythrococca is shaken by the logic of Baillon, who shows that characters based on the number and arrangement of the stamens and of the glands on the receptacle so usually associated with the stamens in this assemblage of types are not of generic significance. Were these the only differential characters available here, Baillon's conclusion is hardly to be questioned.

But while all that Baillon urges with regard to the relative characters afforded by the androecium may be admitted, his reasoning involves an assumption that certain differences in the stamens themselves are unimportant. This assumption does not affect the existence of these differences ; the fact that they exist leaves room for another opinion.

In the species referable to Mercurialis, Linn., in the usual restricted sense, the anther cells at first are pendulous or divaricate. In all those types which

${ }^{1}$ Lamarck, Encyc. Meth., iv. I $20\left(179^{6}\right)$; the plant had already been dealt with by Linnaeus in I 753 (Sp. P1., 980) as a Tragia (T. Mercurialis). Baillon attributes the name M. alternifolia to Desrousseaux, but the authorship of the article Mercurialis is not credited by Lamarck, in the text, to that botanist. Mueller (DC. Prodr., xv. 2, 790) is certainly under a misapprehension in attributing the name to Desvaux.

[Annals of Botany, Vol. XXV. No. XCIX. July, IgrI.] 
Baillon would include in his widened Mercurialis the anther cells at first have an erect position. This character, superadded to those others which Baillon admits to be of sectional value, makes it as easy as it is convenient to treat Mercurialis, Linn., as a distinct genus. But if an intrinsic staminal character may be used for one genus we can legitimately employ such a character in connexion with another. In this way the separation of Seidelia, Baill., is also simple, for in Seidelia the anther cells open longitudinally both in front and behind so that, when their pollen is shed, the anthers are cruciately 4-valved, whereas in Adenocline, Micrococca, and Claoxylon the anther cells open, as Baillon states that they do in Erythrococca, along one side only, 'par une fente longitudinale dont les bords s'écartent beaucoup et se réfléchissent en dehors, de manière à donner à la loge ouverte la forme d'un cornet' (Étud. gén. Euphorb., 437). A criterion from the same source might be used to distinguish the genus Adenocline, Turcz., because in Adenocline the empty anther cells assume the downward position characteristic of those of Mercurialis while still in bud. In this instance, however, the need to rely on a staminal character does not arise; Adenocline is readily separable from the other types under discussion, because the calyx in the male flower is not closed in bud as it is in Mercurialis, Seidelia, Mirococca, Erythrococca, and Claoxylon. At this point, however, staminal characters cease to be effective because the anthers of Micrococca, Claoxylon, and Erythrococca cannot be distinguished at any stage. ${ }^{1}$ Had staminal characters alone been legitimate in the discrimination of the genera with which Baillon deals, the reduction of both Micrococca and Erythrococca to the older genus Claoxylon could be effected without further discussion. In the case of Erythrococca, no one has hitherto suggested that such reduction is necessary; in that of Micrococca it has been effected by Thwaites (Enum. Pl. Zeyl., 27I), whose action has been accepted by Mueller (DC. Prodr., xv. 2, 789 ) and confirmed by Hooker (Flor. Brit. Ind., v. 4I2).

But even if we should grant that it is necessary to merge both Erythrococca, Benth., and Micrococca, Benth., in Claoxylon, A. Juss., this would fall short of accepting the position which Baillon postulates. What Baillon asks us to admit is that in deciding that Micrococca is congeneric with Claoxylon and Erythrococca we must be guided solely by the fact that as regards their stamens the three are indistinguishable; whereas, in deciding that Micrococca is congeneric with Seidelia, Adenocline, and Mercurialis we must treat their staminal differences as negligible. This position has not been accepted by Mueller (DC. Prodr., xv. 2, 775) or by Bentham (Gen. Plant., iii. 309); it is

1 Mueller (DC. Prodr., xv. 2, 789) has stated that in Micrococca the anther cells open introrsely, whereas in Erythrococca (1. c., 790) and in the sections Adenoclaoxylon, Athroandra, Gymmoclaoxylon, and Euclaoxylon of Claoxylon (1. c., $775,776,780,78 \mathrm{I}$ ) they open extrorsely : he is silent as regards Discoclaoxylon, where also they open extrorsely. But, as Bentham has already pointed out (Gen. Plant., iii. 309), there is here some error in observation. An examination of the anthers of Micrococca shows that the cells do not open introrsely. 
a position the acceptance of which seems impossible. But the fact that we are unprepared to adopt his conclusions does not lessen our appreciation of the insight which has led Baillon to realize the crucial importance, in the study of this particular group of types, which attaches to the position of the genus Micrococca. If, in regard to this, the treatment by Bentham be sound, the maintenance of the other allied genera is practically assured, whereas, if that of Thwaites be warranted, the suppression of Erythrococca becomes a logical corollary. But the exhaustion of one line of inquiry does not debar us from taking up another. We are no more bound in this case to concede that staminal characters alone count than compelled to accept the contrary view. It is, therefore, open to us to examine whether Micrococca, Erythrococca, and Claoxylon may not be distinguishable by characters other than staminal.

A detailed revision of the genus Claoxylon, A. Juss. (I824), forms, it should be explained, no part of the purpose of this paper. At the same time, owing to the fact that Claoxylon is older by a quarter of a century than the other two genera concerned, it is necessary to undertake such a general review of this genus as is required for an exact appreciation of the relationship which it bears to its two allies.

In the only monograph of Claoxylon that has yet been attempted, Mueller in 1866 (DC. Prodr., xv. 2, 775-90) subdivided the genus into six sections, characterized as follows :-

$\S$ I. Adenoclaoxylon, Muell. arg.: Dioecious shrubs with perulate buds; stamens mixed with interstaminal glands, and surrounded by an extrastaminal urceolum; anthers opening extrorsely.

$\S$ 2. Athroandra, Hook. f.: Dioecious shrubs with perulate buds; stamens mixed with interstaminal glands, but not surrounded by an extrastaminal urceolum; anthers opening extrorsely.

§ 3. Discoclaoxylon, Muell. arg.: Dioecious trees with non-perulate buds; stamens surrounded by an extrastaminal urceolum, but not mixed with interstaminal glands.

$\S$ 4. Gymnoclaoxylon, Muell. arg.: Dioecious trees or shrubs with nonperulate buds; stamens neither mixed with interstaminal glands nor surrounded by an extrastaminal urceolum; anthers opening extrorsely.

$\S 5$. Euclaoxylon, Muell. arg.: Dioecious trees or shrubs with nonperulate buds; stamens mixed with interstaminal glands, but not surrounded by an extrastaminal urceolum; anthers opening extrorsely.

$\S 6$. Micrococca, Muell. arg.: Monoecious annual herbs with non-perulate buds; stamens mixed with interstaminal glands, but not surrounded by an extrastaminal urceolum ; anthers opening introrsely.

Bentham in 1880 (Gen. Plant., iii. 309) declined to follow Mueller in accepting the suppression of Micrococca proposed by Thwaites. At the same time Bentham refused to recognize the rest of Mueller's sections because the 
receptacular glands in the male flower, the disposition of which is employed in defining the sections, happen to vary somewhat, and to be, as Mueller himself has admitted (DC. Prodr., xv. 2, 775), small and hard to see. This treatment is too severe. Mueller did not rely exclusively upon the disposition of these glands in arriving at the limits of his sections. His primary subdivision is based on the presence or absence of perulae, a character which enabled him to separate his two first sections from the other four ; Micrococca, which is one of these non-perulate sections, has been distinguished from the remaining three by characters unconnected with these glands. Mueller has, indeed, employed the character derived from the buds with considerable restraint; Hooker, who first called attention to it, in 1862 expressed the opinion (Journ. Linn. Soc., vi. 20) that the character probably has a generic significance. But whatever the precise value of the character may be, the fact that Bentham has not alluded to it does not render it negligible. Pax, in 1890 (Nat. Pflanzenf., iii. 5, 48), while agreeing with Bentham as regards the treatment of Micrococca, has not followed the latter in ignoring Mueller's sections. But in considering Mueller's arrangement sufficiently practicable to warrant its retention, Pax has hardly been so critical as he might; the truth lies between his view and that of Bentham. The glands on the receptacle do supply quite valuable characters. But the evidence which these glands afford does not always justify the conclusions arrived at by Mueller, and even when allowance is made for the fact that these glands were not, as Bentham states, used primarily (imprimis) in delimiting Mueller's sections, there is no doubt that undue reliance has been placed upon them for this purpose.

The fact that the suppression of Micrococca has been proposed while no such suggestion has been made as regards Erythrococca renders it desirable to deal with the former before discussing the latter. This necessity therefore entails our discussing first those sections of Claoxylon, proposed by Mueller, which agree with Micrococca in having buds that are not provided with coriaceous bud-scales.

\section{The Non-PERulate Claoxyla.}

The section Discoclaoxylon, Muell. arg., which includes three species that are confined to West Africa and Central Africa, is extremely natural and distinct ; the treatment accorded to it by Mueller has been fully confirmed by the more complete material reported since it was proposed. In this case the character derived from the receptacular glands appears to possess all the weight which Mueller has attributed to it.

The section Gymnoclaoxylon, Muell. arg., which includes two Polynesian species that agree in facies with the bulk of those referred to Euclaoxylon, illustrates on the other hand the justice of Bentham's criticism. One of 
these species, $C$. fallax, Muell. arg., from Fiji, has been referred to Gymnoclaoxylon because Mueller could not find glands on the male receptacle. The male flowers of the original specimens (Seemann, 394) have, however, just as many glands, hirsute at the apex with viscid hairs, ${ }^{1}$ as there are stamens. In the other species, C. sandwicense, Muell. arg. (Linnaea, xxxiv. 165), there are no glands with viscid apical hairs. But associated with the fully developed stamens are many smaller and imperfect ones. These imperfect stamens show every transition from a filament bearing two free or nearly free empty anther cells, to a glabrous receptacular gland. The receptacle in C. sandrvicense does possess glands, and the circumstance that these glands are glabrous does not exclude the species from the section Euclaoxylon. That section contains other species with glabrous glands, among them being C. parviflorum, A. Juss. (Tent. Gen. Euphorb., 43), the plant on which the genus Claoxylon was based. While, therefore, the section Discoclaoxylon, Muell. arg., stands, the section Gymnoclaoxylon, Muell. arg., ${ }^{2}$ is an integral part of Euclaoxylon.

The section Euclaoxylon, Muell. arg., to which, in 1866 , thirty species were referred, but which is now believed to include over forty, has been found since then to be susceptible of some readjustment. Hooker f., in 1887 , when revising the Indian species of Claoxylon (Flor. Brit. Ind., v. 4IO-I4), was under the necessity of recognizing two sections within what corresponds to Euclaoxylon, and under the further necessity of removing from Euclaoxylon another species, C. oligandrum, Muell. arg. (Linnaea, xxxiv. 164), from Ceylon. With the necessity for subdividing Euclaoxylon we do not here require to deal ; this can only be appropriately discussed in connexion with a critical revision of the genus Claoxylon as a whole. The transfer of C. oligandrum from Euclaoxylon does, however, immediately concern us, because of the fact that Hooker has found it most convenient to place this species in Micrococca. Following Thwaites and Mueller, Hooker has treated Micrococca as a section of Claoxylon; to the consideration of this section, or genus, we may now turn.

1 In C. fallax these glands are thin and flaccid; each gland is closely applied to and partially embraces the base of the filament to which it corresponds. When a flower is examined under a simple microscope the appearance presented is practically that described by Mueller of stamens with short silky filaments (DC. Prodr., xv. 2, 780). But if a flower which has been softened in water be kept under observation, as it becomes dry the glands are seen to separate from the filaments, which are perfectly glabrous and are organically free from the glands.

2 The recognition of a section limited in accordance with the definition which Mueller has provided for Gymnoclaoxylon is not, on this account, rendered impossible; there are several species which since $\mathbf{1} 866$ have from time to time been referred to Claoxylon, where there are no receptacular glands. But even if we assume that the reference of these species to Claoxylon be correct and that the recognition of such a section be necessary, that section will not include either of the plants on which Gymmoclaoxylon, Muell. arg., was based, and therefore will not be Mueller's section so named. 


\section{Historical Review of Micrococca.}

The section Micrococca, as understood by Mueller, is monotypic and corresponds with Bentham's genus of the same name. This genus Micrococca was established by Bentham in 1849 (Hook., Niger Flor., 5०3) to accommodate the tropical weed of cultivated ground, widely spread in the Eastern Hemisphere, which supplies Baillon with a title for the paper alluded to in our opening paragraphs. ${ }^{1}$ This plant is so strikingly like Mercurialis perennis, Linn., that in certain states, were its flowers not examined, it might, as Mueller points out (DC. Prodr., xv. 2, 790), be easily mistaken for that species. As early as 1692 Plukenet did indeed treat it (Phytogr., t. 205, fig. 4) as a species of Mercurialis; $M$. maderaspatensis tricoccos acetabulis destituta. Linnaeus chose not to accept this position for the plant, but referred it to Tragia, in 1747 (Flor. Zeyl., 334) as T. foliis ovatis, and again in 1753 (Sp. P1., 980) as T. Mercurialis. This treatment is, however, less satisfactory than that of Plukenet, to which Lamarck independently reverted when, in 1796 (Encyc. Meth., iv. I 20), he described the plant as Mercurialis alternifolia. But Lamarck's view, though more natural than that of Linnaeus, was not adopted by subsequent authors, and the Linnaean treatment was followed until 1849 , when Bentham solved the difficulty by treating Tragia Mercurialis, Linn. (Mercurialis alternifolia, Lamk.), as the type of a distinct genus. But Bentham's proposal, though much more satisfactory than those of Linnaeus and Lamarck, has not been generally accepted ; twelve years later Dalzell and Gibson (Bomb. Flor., 227), Thwaites (Enum. Pl. Zeyl., 27I), and Baillon (Adansonia, iii. I67) independently and simultaneously refused to adopt it. In each of these works a different conclusion was arrived at. Dalzell and Gibson, in I861, while recognizing that the plant in question is not a Tragia when that genus is restricted to its natural limits, were influenced by Linnaeus's arrangement. to such an extent as to believe that it was nevertheless congeneric with Tragia Chamelaea, Linn. (Sp. Pl., 981), a plant which had been shown by A. de Jussieu (Tent. Gen. Euphorb., 39), in $\mathbf{3} 824$, to be a member of another genus, Microstachys, A. Juss. The transfer of Micrococca Mercurialis, Benth., to this genus Microstachys, suggested in the Bombay Flora, is therefore no great improvement on the Linnaean arrangement. This criticism

${ }^{1}$ It would appear that in 1858 Baillon was of opinion that Micrococca Mercurialis, Benth., differed from Mercurialis alternifolia, Lamk. : in his Étude générale, p. 436, he accepted Micrococca as defined by Bentham, while in the same work, p. 490, he treated Mercurialis alternifolia as the basis of a new section (Erythranthe, Baill.) of Mercurialis. But Baillon's Micrococca is not the same as Bentham's; it is made to include Mercurialis tricocca, E. Mey., which is in reality the basis of the distinct genus Leidesia, Muell. arg. (DC. Prodr., xv. 2, 792). In I862, however, Baillon had become satisfied as to the identity of Mercurialis alternifolia with Micrococca Mercurialis and had become aware that Mercurialis tricocca is quite distinct. This last species be now referred to his own genus Seidelia, which he, as already explained, also now treated as a section of Mercurialis, at the same time merging his own Mercurialis $\S$ Erythranthe of $185^{8}$ in Mercurialis \& Trismegisla. 
does not apply to the action of Thwaites in $186 \mathrm{I}$ or to that of Baillon in I862, because both of these authors have fully recognized the real affinity of Bentham's genus. Guided, however, by somewhat different considerations, they have arrived at different conclusions. There is but one species in Ceylon with which Micrococca Mercurialis may readily be compared; the field in which Thwaites had to work was therefore a very restricted one. Knowing that this other Ceylon species had been identified by Baillon with a plant from Java which is undoubtedly a Claoxylon, and finding that as regards their stamens, interstaminal glands, and hypogynous scales this plant and Micrococca Mercurialis entirely agree, Thwaites was left with no option in the matter. His decision to reduce Micrococca to Claoxylon was probably strengthened by the fact that he had, through some inadvertence, formed the impression that Micrococca Mercurialis is a dioecious plant; the fact that it is an annual one has appeared to him too unimportant for mention. Baillon, on the other hand, as we have already seen, satisfied that a striking difference as regards the position of their anther cells is of no real consequence, reverted to the conclusion of Lamarck, and replaced Micrococca in Mercurialis, Linn.

Mueller in I 866 mentioned, but could not accept (DC. Prodr., xv. 2, 775) the conclusion of Baillon; that of Thwaites he adopted in 1865 (Linnaea, xxxiv. I66), notwithstanding his belief that the stamens of Micrococca differ as regards their dehiscence from those of Claoxylon. ${ }^{1}$ But the action of Mueller is less natural than that of Thwaites. In addition to making use of the staminal character in question, Mueller noted that in Micrococca Mercurialis male and female flowers may occur on the same rachis, so that the plant is not dioecious as Thwaites has stated; he further laid stress on the fact, not alluded to by Thwaites, that Micrococca Mercurialis is an annual. Guided by these considerations, Mueller kept the two plants which form the genus Claoxylon, as understood by Thwaites, rather widely apart : Micrococca Mercurialis he treated as the type of a distinct section; the other, which he now recognized as perfectly distinct from the Java plant (Erythrochilus longifolius, Bl.) with which it had been identified by Baillon, he nevertheless placed in his own section Euclaoxylon, with which, except for possessing interstaminal glands in the male flower, it has wonderfully little in common. It is hardly surprising, therefore, that in 1880 , Bentham (Gen. Plant., iii. 309), while he agreed with Mueller in regard to Baillon's conclusion, should have felt unprepared to accept the view, either as stated by Thwaites or as modified by Mueller, that the genus Micrococca should be merged in Claoxylon.

Yet when we examine the arguments employed by Bentham in favour of the maintenance of Micrococca we find them as little convincing as those

1 This belief turns out to be without foundation; the anther cells of Micrococca open precisely as those of Claoxylon proper do. 
which induced Mueller to endorse its suppression. Bentham separates Claoxylon and Micrococca, taken together, from the allied genus Erythrococca, because in both the stigmas are entire, whereas those of Erythrococca are plumosely multifid, and then distinguishes Micrococca from Claoxylon because the former is an annual monoecious herb with few stamens, while the latter is composed of dioecious shrubs with usually numerous stamens. Now this stigmatic character is ineffective; the stigmas in Claoxylon, as Bentham has limited that genus, are not always entire; when Claoxylon is restricted to its natural limits the stigmas never are entire. The statement that the stigmas of Micrococca are entire is incorrect; they have been described by Hooker (Flor. Brit. Ind., v. 4I2) as 'fimbriate'; they may, if we prefer the term, be described as 'plumosely multifid', because they are exactly like the stigmas in most of the species of Erythrococca and in every species of Claoxylon.

Mueller and Bentham are therefore in agreement as regards the characters on which they rely in separating Micrococca from Claoxylon; in both cases the only characters employed which are real are that Micrococca is an annual and is monoecious. In this respect they are at variance with Thwaites, who has not alluded to the first character, and as regards the second laboured under a misapprehension corresponding to the misapprehension of Mueller as regards the nature of the stamens, and to that of Bentham as regards the stigmas. The difference between Bentham and Mueller resolves itself into one of opinion; Mueller believed the two valid characters to be only of sectional value, Bentham considered that they justified the maintenance of Micrococca. as a distinct genus.

Matters remained in this impasse until, in $\mathbf{1} 887$, Hooker threw an entirely new light on the character and composition of Micrococca (Flor. Brit. Ind., v. 4 I 2,4 I 3 ), by pointing out that this section or genus, so far from being monotypic, includes a number of species that are frutescent and dioecious. Besides transferring C.oligandrum, Muell. arg., from Euclaoxylon to Micrococca, and thereby amply vindicating the action of Thwaites in having treated this plant and Micrococca Mercurialis as members of one genus, Hooker added to Micrococca three new forms, C. Wightii, C. Beddomei, and $C$. hirsutum, all natives of Southern India. Of these, C. hirsutum is now believed to be really only a distinct variety of $C$. Wightii; the others are certainly well characterized and valid species which agree with each other, with C. oligandrum, and with Micrococca Mercurialis, and at the same time differ very markedly from every species of Claoxylon proper examined by Hooker, in the character afforded by the scales of their hypogynous disc on which Thwaites laid stress. All these species further differ, as Hooker has pointed out, from every true Claoxylon in having long, filiform, interrupted racemes. ${ }^{1}$

\footnotetext{
${ }^{1}$ In Euclaoxylon and in Discoclaoxyion the racemes when young are substrobilate, when fully
} 
The only species thus transferred by Hooker to Micrococca which was known to Mueller is C. oligandrum. But Mueller was acquainted with another species which belongs to the same group, but which did not come within Hooker's purview. This species is C. capense, Baill. (Étud. gén. Euphorb., 493), a South-East African plant of which neither Baillon nor Mueller knew the male flowers. Now that these are known, it is seen that they are borne on long, filiform, interrupted racemes, and that $C$. capense is a Micrococca and not, as Mueller imagined, a Euclaoxylon (DC. Prodr., xv. 2, 786). ${ }^{1}$ More recently three other species of the same group have been described; these are C. Humblotianum, Baill. (Bull. Soc. Linn. Par., 996), from the Comoros, with $C$. Volkensii, Pax (Engl. Pflanzenw. Ost-Afrik., C, 238), and C. Holstii, Pax (Engl. Bot. Jahrb., xxxiv. 372), both from East Africa. The accession of these additional species shows that the arguments in favour of the widening of Micrococca are stronger even than they were in 1887 , for in $C$. Volkensii the terminal flower of each raceme is a female one, and this species, while agreeing with all the others except Micrococca Mercurialis in being perennial, agrees with Micrococca Mercurialis in being monoecious.

A feature in Micrococca which differentiates it sharply from Euclaoxylon is to be found in the interstaminal glands. The presence of these bodies in Euclaoxylon is constant. In Micrococca, on the other hand, while glands are present in the male flowers of C. oligandrum, C. Wightii, C. hirsutum, and Micrococca Mercurialis itself, there are no such glands in the male flowers of $C$. Beddomei which Hooker, with perfect justice, has associated with the other species mentioned. The same thing is true of C. capense, C. Humblotianum, C. Volkensii, and C. Holstii, all of which have eglandular receptacles. Whatever the value of the character derived from the presence or absence of these glands may be in Claoxylon, in Micrococca that character is merely a specific one.

Another striking peculiarity in Micrococca which is without a parallel in Claoxylon proper has been pointed out by Hooker. In C. oligandrum and in $C$. Beddome $i$ the male flowers are borne on minute distant spikelets, closely covered with imbricating bracteoles, whereas in C. Wightii, C. hirsutum, and Micrococca Mercurialis itself, the male flowers are glomerulate. The

expanded the rachis is continuously floriferous from the top of the peduncle to the apex of the raceme. In 1692 Plukenet suggested that the plant figured by Rheede as Pee-Cupaméni (Hort. Malab., x, t. 82) might be the same thing as Micrococca Mercurialis. In I 753 Linnaeus accepted this suggestion as an established fact. In this Linnaeus has been followed by Dennstedt, Dillwyn, and Hasskarl in their respective works on the Hortus Malabaricus. But in Pce-Cupaméni the racemes are continuously floriferous, and we therefore know that, whatever Pee-Cupaméni may be, the identification of Linnaeus and of those who have followed him is incorrect.

${ }^{1}$ Specimens of $C$. oligandrum sometimes bear so close a resemblance to those of $C$. capense that it is only by dissecting their flowers that the two can be definitely distinguished. The stamens of $C$. oligandrum are always accompanied by interstaminal glands; there are no such glands in the male flowers of $C$. capense. 
same variability is met with among the species of Micrococca which were not known to Hooker. In C. Holstii the male flowers are at the tips of minute bracteolate spikelets as in $C$. oligandrum, in $C$. capense they are in glomerules as in Micrococca Mercurialis itself. The two remaining species are interesting because they are intermediate; $C$. Volkensii has the flowers towards the upper part of the raceme glomerulate as in $C$. Wightii, those lower down on spikelets as in C. oligandrum, while $C$. Humblotianum has the male flowers glomerulate above, but towards the base of the rachis has them on short secondary branches with scattered and not imbricating bracteoles. Here again, then, in spite of its striking nature, the character is only of specific value.

There is, moreover, no definite association between the presence or absence of interstaminal glands and the development or suppression of these spikelets. Of the four Micrococcas which have interstaminal glands three (Micrococca Mercurialis, $C$. Wightii, and $C$. hirsutum) have glomerules, the fourth ( $C$. oligandrum) has spikelets; of the five which have naked receptacles, one (C.capense) has glomerules only, two (C. Beddomei and $C$. Holstii) have spikelets, the remaining two $(C$. Volkensii and $C$. Humblotianum) have both glomerules and either spikelets or short secondary branches.

The conclusion that none of the species enumerated above can be included in the section Euclaoxylon is one that does not admit of doubt. Equally free from doubt is the conclusion, for which we are indebted to Hooker, that they belong to Micrococca. The same certainty, however, does not attend Hooker's further conclusion that the transfer of these species to Micrococca 'requires the suppression of the latter genus' (Flor. Brit. Ind., v. 4IO). ${ }^{1}$ The necessity for this transfer has indeed shown that the characters on which Bentham relied in separating Micrococca from Claoxylon and on which Mueller depended in establishing his section of the same name are not diagnostic. But the fact that their significance was overlooked by Bentham and Mueller does not affect the existence of the important character derived from the nature of the hypogynous disc which we owe to

1 It is a curious fact, and one that is not without a certain degree of interest, that, since I 880 , no British botanist has accepted Bentham's opinion that Micrococca is, after all, a valid genus, while during the same period every Continental botanist has followed Bentham. It is, however, a fact that admits of simple explanation. In I 887 Hooker made the important discovery that Micrococca is not, as Bentham believed, a monotypic genus; whereas in 1900 , when the account of the Euphorbiaceae in the Natürlichen Pflanzenfamilien appeared, Pax overlooked this discovery, and felt justified in accepting, without question, the conclusion at which Bentham had arrived ten years earlier. If Hooker has been followed by Trimen (Handb. Flor. Ceyl., iv. 63), by Hiern (Cat. Afr. P1. Welw., 976), by Cooke (Flor. Bomb. Pres., ii. 609), and by the writer (Beng. Pl., 947), it must be admitted that none of us have added anything to what Hooker did. If Pax has been followed by Schweinfurth (Bull. Herb. Boiss., vii, App. 2, 306), by De Wildeman (Miss. Laurent., i. I 29) and by Durand (Syll. Flor. Cong., 492), it must be equally admitted that none of these have added anything to what was already done by Pax. The acceptance or otherwise of Bentham's view has therefore been the result of accident, except in the case of Hooker to whom we are deeply indebted for having thrown a flood of light on an obscure and difficult question. 
Thwaites, nor does it detract from the value of the still more important character afforded by the inflorescence for which we are indebted to Hooker. By means of these two characters Hooker has brought together, and has enabled others to augment, a compact and natural group of species which, when treated as Hooker has treated it, as a section of Claoxylon, proves to be much more distinct and far more easily separated from Euclaoxylon than Mueller believed it to be. So well characterized is this group and so clearly is it defined by the characters which Thwaites and Hooker have supplied, that the suppression of the genus Micrococca, so far from having been definitely effected, has become once more open to discussion. ${ }^{1}$ The segregation of Micrococca has not been shown to be impossible; it has, instead, been made more simple. Since whatever tends to facilitate the separation of Micrococca makes for the acceptance of the view held by Bentham in preference to that adopted by Mueller, we are at liberty to inquire whether, in spite of the inadequacy of the criteria on which reliance was placed, the judgement of Bentham may not, after all, have been the sounder. Even if we concede that, in the light of the characters employed by Hooker, the evidence for and against the views held by Bentham and Mueller respectively is so evenly balanced as to justify either, one has only to look at the fruit in order to realize that Bentham's instinct was right. In Claoxylon, and in Erythrococca as well, the capsules have coriaceous walls which at first open loculicidally, the two valves of each coccus gaping to expose the seed. At a later stage the segments of the capsule break away septifragally from the relatively wide coriaceous columella. In Micrococca, however, the capsules, with thin crustaceous walls, open simultaneously both loculicidally and septicidally, and thus break up into 2-valved cocci, leaving behind them a slender woody columella. The nature of its fruit dispels all doubt as to the validity of the genus Micrococca and renders its differentiation from Claoxylon and Erythrococca a far simpler matter than the separation of these two genera from each other.

\section{The Perulate Claoxyla.}

The two Muellerian sections of Claoxylon which have still to be considered are Adenoclaoxylon, Muell. arg. (1864), and Athroandra, Hook. f. (1862), as modified by Mueller in 1866. These two sections agree with each other and differ from Discoclaoxylon, Gymnoclaoxylon, Euclaoxylon, and Micrococca in having perulate buds. It is convenient to deal with them

${ }_{1}$ It is largely because Thwaites was justified in referring Claoxylon oligandrum and Micrococca Mercurialis to one genus that there is a doubt as to the limits of that genus. This doubt is due to the uncertainty regarding the former species. Throughout its history the position of the latter has been much discussed, but its specific limits have been tolerably clearly understood. But, in the case of C. oligandrum, Mueller had to point ont in $\mathbf{1} 866$ that its specific identity had been misunderstood both by Baillon and by Thwaites, while in $\mathrm{I}_{8} 7$ Hooker had to indicate that its position and its affinity had been equally misunderstood by Mueller. 
more or less conjointly, but as Athroandra, in its original form, is the older of the two it is desirable to take it into consideration first. When, in I 862, Hooker proposed the section Athroandra (Journ. Linn. Soc. Bot., vi. 20) he pointed out that $C$. Mannii, Hook. f., the species on which the section was based, is 'probably generically distinct from Claoxylon, from all the species of which the perulate buds abundantly distinguish it'. Along with C. Mannii Hooker described another species, C. Burteri, Hook. f. (1. c., 2 I ad calc.), which he referred to the same section. Hooker at the time was unaware, and indeed had no means of knowing, that specimens of the same species had, in 1860 , been described by Baillon (Adansonia, i. 68) as Trewia? africana. ${ }^{1}$ The suggestion of Baillon as to the generic position of this plant lends support, which is stronger for being indirect, to Hooker's belief that Athroandra is generically distinct from Claoxylon. As outlined by Hooker, the section Athroandra is based on species which agree with Mueller's section Euclaoxylon in having the male flowers with only interstaminal glands, but differ from Euclaoxylon in having perulate buds, and in having entire in place of plumosely laciniate stigmas. To the section Athroandra Mueller subsequently added five species which share the same characters:-C. Welwitschianum, Muell. arg. (Journ. Bot., ii. 333); C. columnare, Muell. arg. (Flora, xlvii. 437); C. membranaceum, Muell. arg. (Flora, xlvii. 437); C. angolense, Muell. arg. (Journ. Bot., ii. 333); and $C$. rivulare, Muell. arg. (Flora, xlvii. 518). The justice of Hooker's original view that Athroandra is probably generically distinct is further confirmed by the circumstance that Engler has based on specimens of $C$. rivulare his genus Chloropatane (Bot. Jahrb., xxvi. $3^{8} 3$ ), and that Wright has referred specimens of $C$. Welwitschianum to the same genus (Flor. Trop. Afr., vi. I, I69), under the name Chloropatane Batesii.

The section Athroandra as understood by Mueller is, however, somewhat wider in its limits than the Athroandra outlined by Hooker or the Chloropatane described by Engler and Wright. This is due to the fact that of the two characters, the perulate buds and the entire stigmas, which distinguish Hooker's section, Mueller has relied only upon the first and has treated the second as negligible. This has led him to include in Athroandra

1 The oldest specimens of Trewia? africana were collected in Sierra Leone by Afzelius. These specimens bear a manuscript generic name, the existence of which perhaps indicates that Afzelius, too, had felt that this plant is not congeneric with the plant on which Claoxylon, A. Juss., was subsequently based: prior to 1824 the basis of Claoxylon was regarded as an Acalypha. The specimens on which Baillon hased Trezeia? africana were collected in 1859 by Perrottet in Senegambia, on the banks of the Casamance, long subsequent to the establishment of the genus Claoxylon by A. Jussieu. The specimens on which Hooker based Claoxylon Barteri were collected by Barter in Southern Nigeria-in Lagos Island, at Eppah and in the Yoruba forests. By a typographical error the name Yoruba appears in the Linnean Society's Journal as 'Gomba'. Mueller, when he detected the identity of Claoxylon Barteri and Trezvia? africana, left this typographical error uncorrected and inadvertently introduced another by transferring the provenance of Perrottet's specimens of Trewia? africana from the banks of the Casamance to the neighbourhood of the Niger. 
three species:-C. panciflorum, Muell. arg.; C. trichogyne, Muell. arg.; and C. triste, Muell. arg. (Journ. Bot., ii. 333, 334); all of which agree with Euclaoxylon, but differ from Hooker's Athroandra, in having the stigmas plumosely laciniate and in having the hypogynous scales which alternate with their carpels discrete, whereas in Athroandra these scales, if free, are contiguous by their margins under the base of the ovary; more usually, however, they are connate in a disc. In the case of $C$. trichogyne and C. triste, moreover, the ovaries are densely strigose, whereas in every true Athroandra the ovary is glabrous; the stipules, too, are accrescent and harden into cartilaginous bosses or thornlets, whereas in every true $A$ throandra the stipules, although hyaline-scarious, are very minute and do not become altered or enlarged. But while it is, at least, inconvenient to include these species in Athroandra, their generic relationship is almost certain; the perulate buds, as Mueller remarks (DC. Prodr., xv. 2, 779), undoubtedly indicate their affinity.

The section Adenoclaoxylon, based on a solitary species, C. Kirkii, Muell. arg. (Flora, xlvii. 436), is as distinct and natural as the section Athroandra when taken in the sense outlined by Hooker. Now, however, that seven species belonging to this section are known, it is found that the arrangement of the receptacular glands, used by Mueller along with the character of perulate buds in its definition, is not constant. As originally described, the section differs from Athroandra and from Euclaoxylon by the presence of a ring of extrastaminal glands. But this extrastaminal ring may be imperfect or altogether absent, and the distinctive feature of the section, apart from the perulate buds, is the circumstance that the male flowers are in axillary glomerules, whereas in the rest of the genus these are in racemes. All the species in the section share with $C$. trichogyne and $C$. triste accrescent spinulous stipules, discrete hypogynous scales, and plumosely laciniate stigmas, and differ in these three characters from every true Athroandra. These three characters the section further shares with the genus Erythrococca, Benth. (Hook., Niger Flor., 5c6), to the consideration of which we may now give our attention.

\section{Historical Review of ERythrococca.}

The genus Erythrococca was founded by Bentham on specimens of a plant collected in Sierra Leone by Vogel and in Senegambia by Heudelot. But specimens of the same species, collected in Sierra Leone by Smeathman, had already been described by Poiret, in $\mathrm{I} 8 \mathrm{r} 0$, as Adelia anomala, Juss. (Encyc. Meth. Suppl., i. I32). Poiret only describes the female flowers; his general account contains the statement that the leaves are axillary to the spines, but omits to note the perulate buds. In I $824 \mathrm{~A}$. de Jussieu dealt again with some of Smeathman's specimens (Tent. Gen. Euphorb., 32). He had male specimens before him, even if Poiret had not any; if he had a female 
specimen it had no flowers. But de Jussieu's description of the male flower is not altogether clear, and his statement that the stamens are numerous (plurima) is not accurate. Poiret's account of the relative position of the leaves and spines is accepted by de Jussieu, who also omits to note that the buds are perulate. The animadversion on Poiret's account of the female flower is hardly called for: Poiret's description is correct so far as it goes, though it fails to state that the ovary is adpressed strigose and is subtended by hypogynous scales. Still Jussieu's explanation of Poiret's supposed error is interesting from its reference to the fact that in this species the male pedicels are jointed well above the base. Neither Poiret nor A. de Jussieu allude to the fruit or the seed. ${ }^{1}$ But, as Bentham has indicated, to A. de Jussieu belongs the merit of pointing out that this species, owing to the nature of its anthers, is more nearly allied to Claoxylon than to Adelia.

The account of Erythrococca given by Bentham when, in 1849 , he founded the genus, is somewhat brief. It points out that the spines are stipular and that the stamens are definite, thereby removing two previous misapprehensions. But there is no reference to the bud-scales, to the presence of receptacular glands in the male flower, to the fact that the ovary is strigose, or to the existence of hypogynous scales. The account of the stamens implies that they are I-seriate and states that the filaments are connate in a ring. The fruit is said to be 'apparently' indehiscent, with a thin fleshy pericarp and a crustaceous endocarp.

The account of Erythrococca by Baillon (Étud. gén. Euphorb., 437) in 1858 deals at some length with the male receptacular glands, which are interpreted as a double disc. The stamens are described as more than I-seriate, though the details given differ from those which are usual; the filaments are again interpreted as united at the base. Nothing is added to Bentham's account of the fruit, and Baillon does not note that the buds are perulate or that the ovary is strigose and subtended by hypogynous scales. This last omission was very soon rectified (Adansonia, i. 7I); Baillon also soon discovered that the stamens are not always limited to a particular number (Adansonia, iii. I74).

A fuller account of Erythrococca was given by Mueller (DC. Prodr., xv. 2, 790) in 1866 . The calyx is usually 3 -partite, as Mueller says; occasionally, however, the male calyx may be 4 -lobed. The stamens, though usually $6-7$, as he states, may at times be more numerous; II is the highest

1 Poiret explains that he saw specimens, collected by Smeathman, in the herbaria of A. L. de Jussieu and of Desfontaines. It is possible that A. de Jussieu only saw the specimens which had belonged to A. L. de Jussieu. It is also possible that neither of these herbaria had received fruiting specimens of Smeathman's plant, and it is further possible that A. L. de Jussieu never received a female specimen: Poiret's account of the female flower may have been based on a specimen which belonged to Desfontaines. But these questions happen to be of no practical consequence here, because the ample suite of specimens of this species collected in Sierra Leone by Smeathman, which is preserved in the British (Natural History) Museum, includes both sexes and also shows ripe fruits. 
number so far observed. More important, however, is the account of the receptacular glands. Mueller describes those that constitute an extrastaminal ring as produced radially inwards between the filaments, and as confluent with the interstaminal glands so as to form the 'double disc' mentioned by Baillon, within which the stamens are enclosed. What Mueller describes is precisely what is seen when a carefully soaked flower is examined under a simple microscope. But when such a flower is kept under observation while it is parting with its extraneous moisture, the glands of the two series are seen to separate spontaneously, and to be in reality quite free. The confluence proves to be no more than an adhesion of these viscid bodies while they are wet; there is no organic union between the glands of the outer and the inner series. In Erythrococca aculeata, Benth., the receptacular glands are unusually large, about as long as the stamens; in Claoxylon (Adenoclaoxylon) Kirkii they are relatively small, shorter than the filaments. But in these two plants the receptacular glands do not otherwise differ; they are identical in character and are arranged in the same manner. Mueller does not remark that the buds of Erythrococca are perulate or that the ovary is adpressed strigose. He says nothing with regard to the seed, and his account of the fruit is taken from Bentham. He appears to accept as a fact what with Bentham was little more than a suggestion, and indicates (DC. Prodr., xv. 2, 79I) his belief that it is only because its fruit is indehiscent that Erythrococca may be distinguished from Claoxylon.

In the revised definition of Erythrococca, published in 1880 by Bentham (Gen. Plant., iii. 308), the spines are described as infra-stipular. The number of stamens is now admitted to vary, but the filaments are still said to be connate in a ring. The presence of hypogynous scales in the female flower is accepted, but the existence of receptacular glands in the male flower, though in this species these glands are so large as almost to conceal the stamens, is not mentioned. The fruit is now said, without any reservation, to be indehiscent, with a thin fleshy exocarp and a crustaceous endocarp, but it is suggested that it may not always be monococcous. The spines are, however, as Bentham had stated in 1849 , the stipules themselves. Under other circumstances the question as to whether the filaments be free as Mueller implies, or connate below as Bentham and Baillon suppose, might have been open to doubt. Had there been no interstaminal glands in the male flower, the structure which the attachment of these glands proves to be a receptacle might, without serious objection, have been interpreted as a short staminal 'column'. But even if this alternative explanation had been permissible, there is nothing in the appearance or the anatomy of this receptacle to suggest that it is 'annular'.

In 1890 Pax (Nat. Pflanzenf., iii. 5, 48) accepted the limitation of Bentham and Mueller. His brief diagnosis corrects the misapprehension 
of 1880 as regards the spines, but omits any reference to the fruit. In the generic key which precedes his diagnosis, Pax has substituted for the character which in 1866 Mueller believed to be the only mark of distinction between Erythrococca and Claoxylon, alternative characters derived from the stamens and stigmas. ${ }^{1}$

Up to this point the history of Erythrococca has been that of a monotypic genus. In I894 a new phase in this history was initiated by Pax, whose prolonged and fruitful study of the African Euphorbiaceae has been so rich in interesting results. In 1889 Schweinfurth collected in Arabia a plant previously obtained there by Deflers. This species, treated by Deflers as perhaps a Mercurialis (Voy. Yemen, 203), was distributed by Schweinfurth (P1. Arab. Fel. exsicc. 933) as a Claoxylon. In 1892 Schweinfurth and Riva met with the same species in Abyssinia. On this occasion, as the sheets he distributed indicate, Schweinfurth concluded that the plant was not a Claoxylon, but must be either an Erythrococca or the type of a new genus. Deciding in the latter sense, he named the species Deflersia erythrococca, Schweinf. (Penzig in Atti Congr. Bot. 1892, Genova, 359). In I $894 \mathrm{Pax}$ referred this plant to Erythrococca, as E. abyssinica, Pax (Engl. Bot. Jahrb., xix. 87); to this view Schweinfurth has since assented (Bull. Herb. Boiss., vii, app. 2, 306). If Erythrococca be indeed a valid genus, this action is fully justified; Deflersia, Schweinf., and Erythrococca, Benth., agree in having perulate buds, accrescent indurated stipules, both extrastaminal and interstaminal receptacular glands, discrete hypogynous scales, and free, linear, plumosely laciniate stigmas; they mainly differ in that the ovary in Deflersia is glabrous, but in Erythrococca is strigose, while in Erythrococca the stipular spines and the receptacular glands are larger than in Deflersia. Along with E. abyssinica, Pax added two other species to Erythrococca (Engl. Bot. Jahrb., xix. 88). One of these species, E. Fischeri, $\mathrm{Pax}$, is interesting because it serves as a connecting link between Deflersia, Schweinf., and Clao ylon $\S$ Adenoclaoxylon, Muell. arg. ; the other, E. bongensis, $\mathrm{Pax}$, is a genuine Adenoclaoxylon. In thus widening the limits of Erythrococca, Pax has not stated what differential characters were relied on by him in distinguishing the genus from Claoxylon, though he has made it clear that he was not practically influenced by the criterion on which Mueller relied in $1866,{ }^{2}$ and that he was not guided by the criteria employed by himself in $1890 .^{3}$ The omission was, however, rectified in 1895 (Engl. Pflanzenw. Ost-Afrik., C, 238), when Pax supplied a new diagnosis; the only

1 The characters adduced (1. c. 47) are: Erythrococca; stamens $3^{-6}$; styles short, plumosely laciniate, free from the base: Claoxylon; stamens usually numerous; styles linear, entire.

2 Of the three species thus for the first time added to Erythrococca, the female flowers and fruits were unknown in $E$. Fischeri and $E$. bongensis, and although the female flowers of $E$. abyssinica are described there is no account of the fruit.

${ }^{3}$ Claoxylon lasiococcum, Pax (Engl. Bot. Jahrb., xix. 87), described at the same time as these three species of Erythrococca, has plumosely laciniate and not entire stigmas. 
character included in this which is not also applicable to Claoxylon, is that Erythrococca has stipular thorns. ${ }^{1}$

When providing this new criterion for the genus Pax added a fifth species, E. mitis, which is certainly an Adenoclaoxylon, and is admittedly very nearly allied to Claoxylon Kirkii itself. More recently Rendle has added another Adenoclaoxylon to Erythrococca, E. Paxii, Rendle (Journ. Linn. Soc. Bot., xxxvii. 212), as nearly allied to E. Fischeri as E. mitis is to Claoxylon Kirkii; while Pax has described yet another, E. rigidifolia, Pax (Engl. Bot. Jahrb., xliii. 320 ), as nearly allied to E. bongensis as E. Paxii is to E. Fischeri. Every known Adenoclaoxylon has now been formally referred to Erythrococca except Claoxylon Kirkii, Muell. arg., the species on which the section was based.

Along with E. rigidifolia, Pax added to Erythrococca a species, E. hirta, Pax (Engl. Bot. Jahrb., xliii. 321), which is neither an Adenoclaoxylon nor a Deflersia, but is nearly allied to Claoxylon trichogyne, Muell. arg., one of the species added to Athroandra by Mueller which do not, on account of their laciniate stigmas, conform with that section as it was originally outlined. To this group belong, in addition to $E$. hirta and $C$. trichogyne, the following species described under Claoxylon:-C. triste, Muell. arg.; C. lasiococcum, Pax (Engl. Bot. Jahrb., xix. 87) ; C. Menyharthii, Pax (Bull. Herb. Boiss., sér. 2, i. 877); C. Mildbraedii, Pax (Engl. Bot. Jahrb., xliii. 80). All six agree in having stipular thorns, densely hirsute ovaries, and plumosely laciniate stigmas; where one of them is definitely placed the others must go. If Erythrococca be a valid genus, the reference thereto of E. hirta is as justifiable as was the reference to that genus of $E$. abyssinica; although the other five species named have not yet been formally included in Erythrococca, this does not lessen our indebtedness to Pax for having so enlarged our conception of the genus as to render it capable of accommodating any species, hitherto accounted for under Claoxylon, which combines the characters of perulate buds, stipular thorns, and plumosely laciniate stigmas.

The question that has first to be settled, therefore, is as to whether Erythrococca be really distinct from Claoxylon. The affinity between the two genera has been fully admitted since it was pointed out by A, Jussieu in 1824 ; the settlement of the question involves a scrutiny of the criteria which have from time to time been relied upon for their discrimination. These criteria have been three in number:-(I) that formulated by Mueller in 1866 ; Erythrococca has an indehiscent, while. Claoxylon has a capsular fruit: (2) that employed by Pax in I890; Erythrococca has 3-6 stamens and plumosely laciniate stigmas, while Claoxylon has usually many stamens and always entire stigmas: (3) that substituted by Pax in 1895 ; Erythrococca has stipular thorns, while, by implication, Claoxylon is unarmed.

1 It is not clear that this was the criterion relied on in 1894 , because C. lasiococcum is one of the species with stipular thorns. 
Before Mueller's criterion can be considered it is desirable to provide, what so far has never been fully given, an account of the fruit and the seed of Erythrococca aculeata, Benth. The fruit of this species ${ }^{1}$ is occasionally 3-coccous, all three carpels becoming fully developed; more often it is 2 -coccous and didymous, not infrequently it is, by abortion, I-coccous. The cocci are subspherical and have, when ripe, a dull green, sparingly setose, thinly coriaceous pericarp which opens loculicidally so as partially to expose the seed. The seed, which is almost globose, is completely enveloped in a bright scarlet arillus, organically quite free from the hard, crustaceous, nearly black, rugosely foveolate-reticulate testa. The albumen is fleshy, the conspicuous axile embryo has a conical radicle with two flat, expanded, suborbicular cotyledons. The coriaceous valves of the cocci remain long attached to the flat, subspathulate, flexible columella which is tipped by the marcescent stigmas; often the valves fall away before the seeds become detached. The accounts hitherto given of the fruit of $E$. aculeata have been incomplete descriptions of the seed; what has been termed a fleshy exocarp (Gen. Plant., iii. 308) or a thin sarcocarp (Engl. Bot. Jahrb., xix. 89 ) is the arillus, the crustaceous endocarp being the testa. We have seen that, although this is the only character on which Mueller relied in distinguishing. Erythrococca from Claoxylon, it has not been used for this purpose by Pax. That author has, however, placed a certain amount of dependence upon the criterion in another connexion. An interesting plant collected in fruit by Pogge on the river Lulua, a tributary of the Congo, which has the perulate buds, the stipular thorns, and the plumosely laciniate stigmas of Erythrococca, has been treated by Pax as the type of a distinct genus Poggeophyton (Engl. Bot. Jahrb., xix. 88), partly because the glands which surround the base of the ovary differ from the hypogynous scales of $E$. aculeata, and partly because it has a dehiscent capsule. The fruit of Poggeophyton aculeatum, Pax, is, however, quite like that of Erythrococca aculeata, Benth., and the only difference in the seeds of the two is that in Poggeophyton aculeatum the arillus does not completely envelop the testa. The necessity for treating Poggeophyton as a genus apart from Erythrococca therefore rests on a difference in the appearance and disposition of the component parts of the hypogynous 'disc' in the two plants.

The two criteria employed by Pax in 1890 differ from the one relied upon by Mueller in 1866 in being real and not imaginary. As the staminal criterion is not looked upon by Pax as an absolute one, it is more convenient to consider the two separately. In considering them it is, moreover, necessary to take into account the circumstances under which they

1 This account is based on an examination of $(a)$ the original specimens of Adelia anomala, Juss., collected by Smeathman in Sierra Leone; $(b)$ the original specimens of Erythrococca aculeata, Benth., collected by Vogel in Sierra Leone; (c) specimens of the same species collected by Scott Fllict in Sierra Leone. 
were enunciated. Since these criteria were laid down, the limits of the genus Erythrococca have been extended, and this extension has involved the substitution of a new criterion. Our examination of the two characters must therefore have regard only to their applicability to a state of affairs in which Erythrococca was still looked upon as a monotypic genus, which had to be discriminated from a Claoxylon that, except for the removal therefrom of the genus Micrococca, Benth., was limited and subdivided in accordance with the system devised by Mueller in 1866 . The stamens in Erythrococca are rarely, if ever, fewer than 6 ; they may be as many as $11 .{ }^{1}$ In the section Adenoclaoxylon, as known to Mueller, the number of stamens is 7-8; in Discoclaoxylon the number is 6-12. In C. trichogyne and C. triste, the two species with stipular thorns and plumosely laciniate stigmas which Mueller added to Athroandra, but which do not belong to that section in its original sense, the male flowers are still unknown. But in E. hirta, Pax, which is so nearly allied to $C$. trichogyne that the two may be conspecific, there are only 10 stamens; in C. Menyharthii, Pax, which is equally nearly allied to $C$. triste, there are only 2-5 stamens. This staminal criterion is, on the whole, adequate so far as Mueller's sections Gymnoclaoxylon and Euclaoxylon ${ }^{2}$ are concerned; it is also applicable to that portion of Athroandra, Muell. arg., which corresponds with the true Athroandra, Hook. f. But it is ineffective so far as Mueller's sections Adenoclaoxylon and Discoclaoxylon are concerned, and is probably equally so as regards that portion of Athroandra, Muell. arg., which does not belong to Athroandra, Hook. f.

The stigmatic criterion used by $\mathrm{Pax}$ in I 890 happens to be less effective as between Erythrococca, Benth., and Claoxylon, A. Juss., than the

1 The experience of Bentham and Pax that the stamens may be fewer than 6 must be looked upon as, at least, somewhat exceptional. It is opposed to the experience of Mueller, who appears usually to have met with 6 , occasionally with $7 ; 5$ in an outer series, with always at least one quite central. In view of this conflict of experience, close attention has been given to this question, and no apology is needed for a statement of what has so far been actually observed. The usual arrangement is precisely that described by Mueller; no flower examined has been met with in which the outer series of 5 stamens was incomplete, nor has one been seen in which this outer series was unaccompanied by at least one central stamen. But very often there are $2-3$ central stamens; occasionally there are 4-5 central stamens, and when this is the case these 4 or 5 are definitely disposed in a second (inner) series, accompanied by an additional ring of receptacular glands. Very rarely, when there are two complete series of stamens $(5+5)$, an eleventh quite central stamen is present ; this eleventh stamen, however, is hardly ever perfect; usually it has no anther; sometimes it has anther cells with no pollen. In flowers with 9-II stamens the male calyx has always been found to be 4 -partite; when there are $7-8$ stamens the calyx is usually 4 -partite. When the calyx is 3-partite there are almost always 6 stamens arranged as Mueller describes; occasionally, however, 3-partite calyxes may have 7 stamens, very rarely may have 8. A central imperfect stamen, exactly like that occasionally seen in $E$. aculeata, occurs frequently, though by no means invariably, in Claoxylon Menyharthii, and has been interpreted by Brown (Kew Bull. I909, I 4I) as a rudimentary ovary (C. virens, N. E. Br.).

2 It is, however, only because of Hooker's discovery that C. oligandrum, Muell. arg., is not an Euclaoxylon but a Micrococca that we are in a position to make this statement, because in $C$. oligandrum we sometimes find 5 stamens. 
staminal one is. In every species where the female flowers are known the stigmas are plumosely laciniate throughout Mueller's sections Discoclaoxylon, Adenoclaoxylon, Gymnoclaoxylon, and Euclaoxylon. Even in the case of Athroandra, Muell. arg., the character is ineffective because Mueller has added to Anthroandra, Hook. f., three species, C. trichogyne, triste, and pauciflorum, which have plumosely laciniate stigmas. ${ }^{1}$ The criterion, as between Erythrococca and Claoxylon, instead of being generally applicable, is only effective in separating from Erythrococca, Benth., the section Athroandra when that section is limited in accordance with Hooker's original intention.

The fact that a character may not prove effective in a particular direction does not, however, necessarily deprive it of value. In the present case this stigmatic character enables us to rectify the misapprehension entertained by Mueller with regard to the natural limits of the section Athroandra, Hook. f. But the character does more than this; it confirms from an independent source the opinion of Hooker that Athroandra is probably generically distinct from Claoxylon. Were this, indeed, the only character which had to be considered, the logical result of its application would be the simultaneous reduction of Erythrococca to Claoxylon.

We have, however, yet to consider another criterion which has been held by Pax to justify at once an extension of the limits of the genus Erythrococca, and the separation of that genus from Claoxylon. This criterion, suggested in 1895 , is that Erythrococca may be recognized by the presence of stipular thorns. There is no doubt that the character is an important one. In the original E. aculeata, Benth., the thorns are so large as to compel attention, but in the three species of Claoxylon known to him in which the character is obvious (C. Kirkii, trichogyne, and triste) Mueller has treated it as negligible. ${ }^{2}$ The criterion, as we have already seen, may be used to a greater extent than Pax has yet formally used it. It does not conflict with any other salient character; there is no species with stipular thorns which does not at the same time have perulate buds and plumosely laciniate stigmas. The only difficulty is that the criterion does not take us quite so far as these two other characters, used in conjunction, happen to carry us; there is one species, C. pauciflorum, which has perulate buds and plumosely laciniate stigmas, where the stipules remain unmodified. The perulate buds indicate that $C$. panciflorum should be associated either with Erythrococca (including Adenoclaoxylon) or with Athroandra, yet the nature of the stipules excludes it from the former, the character of the stigmas prevents its reference to the latter.

1 It is largely because these three species exhibit this character, whereas the stigmas of every true Athroandra are entire, that Mueller's treatment of the section is unsatisfactory.

2 It is not stated why the character was considered unworthy of reference. But we know that it cannot have been overlooked, because Welwitsch, in his field-notes regarding C. trichogyne, expressly calls attention to the nature of the stipules (Cat. Afr. Pl. Welw., 975), and we also know that Mueller had access to these field-notes. 
The chief objection to the exclusive employment of either the stigmatic or the stipular character is that both suggest a cleavage plane which intersects that indicated by the presence or absence of cartilaginous bud-scales, treated by Hooker as perhaps of generic, and by Mueller as certainly of sectional significance. ${ }^{1}$ In their neglect of this character Bentham and Pax have only done what Mueller has done as regards both the stigmatic and the stipular ones. The action in both cases is quite legitimate; its explanation probably is a wișh to avoid the simultaneous employment of characters which act at cross purposes. But the fact that they were not made use of by Mueller has not rendered the stigmatic and the stipular criteria less valuable; the fact that Bentham and Pax have not employed them leaves unaffected the importance of the bud-character pointed out by Hooker. When we find that, useful and valuable as they are, the stipular and stigmatic criteria alike fail to effect the complete and satisfactory differentiation of Erythrococca from Claoxylon which is desired, it is permissible to examine more closely the result of the application of the character afforded by the presence or absence of cartilaginous bud-scales.

When Hooker's character is treated as the primary one, we find that those species which have perulate buds, and at the same time have stipular thorns (Erythrococca as amplified by Pax), always agree with the nonperulate species (Claoxylon proper) as regards stigmas, while one half of them agree as regards male flowers. Those species with perulate buds, which at the same time have entire stigmas (Athroandra in the original Hookerian sense), always differ from the non-perulate species (Claoxylon proper) as regards female flowers, and with one exception ${ }^{2}$ differ also as regards male flowers. It is clear, when this line of inquiry is taken, that Athroandra, Hook. f., is entitled to generic recognition as apart from Claoxylon. Nor in the case of Erythrococca, as amplified by Pax and as apart from Athroandra, is there room for serious doubt. It is permissible to argue that, where there is such substantial agreement as regards floral structure, no single character, even when so striking as that afforded by the presence of stipular thorns, can suffice to justify the recognition of a genus. But the argument is not really sound. The important character on which Pax has based his judgement does not stand alone; it is only ancillary to the still more important character of perulate buds. When this is realized all doubt as to the desirability of separating Erythrococca from Claoxylon disappears.

1 According to the system of subdivision employed by Mueller in the case of Claoxylon, which is based conjointly on the presence or absence of bud-scales, and on the disposition of the receptacular glands in the male flower, the two sections Athroandra and Euclaoxylon agree as regards the latter, and are only distinguishable by the former character.

${ }^{2}$ C. membranaceum, Muell. arg., which, now that its male flowerg are known, is found to have the filaments longer than the anthers, as is the case in Claoxylon proper and in all the species that have stipular thorns. In every other species which has entire stigmas the anthers are subsessile. 
The question remains as to whether Erythrococca, as enlarged by Pax, and Athroandra, Hook. f., constitute two distinct genera, or if they may be treated as integral parts of one natural genus. As genera in Euphorbiaceae go, no great harm could accrue were they kept distinct ; their discrimination would certainly present no difficulty. But while their separation would be a simple matter it does not appear to be necessary. In the first place the stipular character, which is perhaps unequivocal so far as the distinction between Erythrococca and Claoxylon is concerned, is not so definite as indicating a distinction between Erythrococca and Athroandra. The stipules in Athroandra, it is true, remain minute and unmodified. But these organs are not, in Athroandra, normal stipules; they are firm, persistent, hyaline or scarious bodies that, even in those species which have pubescent twigs and petioles, are polished and glabrous. They differ in degree rather than in kind from stipules of the Erythrococca type. In all those species which can be referred to Erythrococca, as understood by Pax, the stipules are accrescent, the filaments are longer than the anthers, the stigmas are plumosely laciniate, and the hypogynous scales which alternate with the carpels are free and discrete, or very rarely are accompanied by smaller additional scales. In all the species which can be referred to Athroandra, Hook. f., the stipules remain unmodified, the anthers are subsessile, the stigmas are entire, and the hypogynous scales which alternate with the carpels are rarely free, and if they be free are contiguous at their margins under the ovary; more usually they are connate in an urceolate disc. There is, however, one species with perulate buds, C. pauciflorum, Muell. arg., which has the stamens, the hypogynous scales, and the stigmas of Erythrococca, with the unmodified stipules of Athroandra. On the other hand, there is a perulate species, C. membranaceum, Muell. arg., with the unmodified stipules, the entire stigmas, and the contiguous hypogynous scales of Athroandra, which has anthers borne on long filaments, as in Erythrococca. These two species, one a somewhat aberrant Erythrococca, the other a somewhat aberrant Athroandra, serve as links between the groups to which they severally belong. The intimate relationship of these groups is further indicated by a third species with perulate buds, $C$. polyandrum, Pax and K. Hoffm. (Engl. Bot. Jahrb., xlv. 237). As regards the sum of its characters this species resembles $C$. panciflorum so much that it may be looked on as the East African representative of that Angolan plant. It combines the anthers with long filaments and the discrete hypogynous scales of an Erythrococca with the unmodified stipules of an Athroandra. The stigmas, however, are curiously intermediate ; they are ovatelanceolate and divaricate, and are borne on a distinct, if short, style, exactly as they are in one-third of the species of Athroandra. But in place of being entire, as they always are in Athroandra, the stigmas of $C$.polyandrum have incised lobulate margins. They thus approach the plumosely laciniate 
type of stigma characteristic of Erythrococca, to which group, in spite of its markedly aberrant features, $C$. polyandrum is most conveniently referred. The existence of these intermediate species justifies the treatment of Athroandra as a sub-genus of an Erythrococca somewhat wider even than Pax has indicated; the criterion which distinguishes this enlarged Erythrococca from Claoxylon, A. Juss., is that it has perulate buds, while Claoxylon has not.

Throughout this genus, in spite of the differences as regards hypogynous scales and stigmas which occur in the species of its two sub-genera, the fruit and the seed are remarkably uniform, and the account already given under $E$. aculeata is applicable to the fruit of all its congeners except that in the majority we find no hairs on the pericarp, and that in a few the arillus does not quite envelop the testa.

Mueller (DC. Prodr., xv. 2,775) terms the fruit in Claoxylon-which genus, as understood by him, included Claoxylon itself as here understood, Micrococca as here understood, and the whole of Erythrococca as here understood, except E. aculeata, Benth.-capsular, 2-3-coccous. This characterization is sufficiently general to admit of its employment for all three genera. The seed Mueller speaks of as ecarunculate and as covered by a coloured epidermis which soon becomes loose. This 'epidermis' is the arillus; it never becomes loose, because it shows no trace, at any stage, of organic union with the testa. Welwitsch, on the other hand, refers, in the case of $C$. pauciflorum, to a fleshy endocarp (Cat. Afr. Pl. Welw., 975); on examination Welwitsch's specimens show that this 'endocarp' is the arillus; there is no trace of organic union between it and the pericarp. The arillus is viscid, as Welwitsch remarks under $C$. Welwitschianum; it therefore sometimes adheres, now to the seed coat which it overlies, now to the inner wall of the pericarp which encloses it. The apparently incompatible interpretations of Mueller and Welwitsch are thus not only readily intelligible but easily reconciled. The seeds of $C$. Welwitschiamum and of $C$. triste are said by Welwitsch to have an arillode, but his own specimens show that the structure is really an arillus.

Bentham (Gen. Plant., iii. 309) speaks of the seed of Claoxylon-the genus being understood by him as it was by Mueller, except that it does not include Micrococca - as 'estrophiolate'; he does not mention the arillus. ${ }^{1}$ The fruit of Claoxylon is said by Bentham to break up into 2-valved cocci (capsula in coccos 2-valves dissiliens). This description applies only in a qualified sense to any species of the sections Adenoclaoxylon or Athroandra, which we have now transferred to Erythrococca. The same qualification is needed in the case of the section Discoclaoxylon, where the cocci, though

1 The first author to allude definitely to the fact that the seed in Claoxylon is arillate was Kurz (For. Flor. Brit. Burma, ii. 395): Kurz had, however, the advantage of having collected the fruits and examined the seeds of cerlain species of Claoxylon in the field. 
larger than in any Erythrococca and densely velvety outside, are again green and coriaceous when ripe, and open loculicidally without shedding their valves to expose the seeds, which in this case are bright yellow. In the case of the section Euclaoxylon (including Gymnoclaoxylon) the fruits and seeds are, at least as a rule, indistinguishable from those of Erythrococca, though it is stated by Hooker (Flor. Brit. Ind., v. 410) that in Claoxylon there are species with cocci which, besides being coriaceous, may be indehiscent, and that in some of the species the seed may have no arillus. ${ }^{1}$ It is true that ultimately in Claoxylon, as in Erythrococca, the two half valves of the cocci fall away, but there is no splitting of the septa such as is met with in the species of the allied genus Micrococca, to the fruits of which the description given by Bentham is strictly applicable.

A character, more interesting than important, which at first sight appears almost distinctive of E. aculeata, on which the genus Erythrococca was based, deserves to be noted. The pedicels in the male flowers of Erythrococca are articulate. The articulation is usually opposite or below the tip of the corresponding bracteole; the portion of the pedicel under the joint is, as a rule, appreciably thicker than the portion above $;^{2}$ in cases where the rachis is pubescent while the pedicel is glabrous, the thicker pedicel base is often pubescent like the rachis, and not glabrous like the rest of the pedicel. In $E$. aculeata the joint is considerably above the level of the bracteole. But this feature is not peculiar to $E$. aculeata; it is well marked in Claoxylon Menyharthii, which differs considerably from $E$. aculeata, and in E. natalensis and E. berberidea, which differ considerably from both the foregoing. The meaning of this difference in the position of the articulation from that which usually obtains is not obvious; it is, however, so far as classification is concerned, only of specific value.

Another curious character met with in $E$. aculeata is that the male calyx is partite only to the middle, leaving below the teeth a distinct campanulate tube. In two other species, E. berberidea and E. subspicata, the calyx is two-thirds partite, but in the genus as a whole the calyx is partite almost to the base. This departure from the general rule is associated with a divergence from the usual conditions as regards the receptacular glands. In E. aculeata these are unusually large, as long as the stamens; in E. berberidea and E. subspicata they are also large, as long as the filaments; as a rule these glands are relatively small, generally minute. The horizontal plane to which division of the calyx extends in each case practically coincides with the level of the points of origin of the viscid apical

1 The possible association of exarillate seeds and indehiscent cocci is one that will doubtless receive the attention it merits from whoever may prepare the revision of which the genus Claoxylon stands urgently in need.

${ }^{2}$ In the case of $C$. columnare, Muell. arg., the condition has been fully and correctly clescribed by Mueller (DC. Prodr., xv. 2, 776); the character, however, is a generic and not, as Mueller's treatment seems to imply, a specific one. 
hairs ${ }^{1}$ so generally met with in the male flower; what at first seems a striking difference is therefore in reality only a case of conformity with a general rule.

In speaking of the bodies which bear these viscid hairs the term ' receptacular glands', used by Bentham, is preferable to the term 'disc' employed by Baillon and Mueller in the case of $E$. aculeata, and less definitely by Mueller as regards Claoxylon generally. ${ }^{2}$ The word 'disc', owing to the wide morphological interpretation which it permits, is rather unsatisfactory, and its use, so far as the genus Erythrococca is concerned, is not altogether convenient. In some of the more nearly allied genera these glands are staminodes and show every transition from a perfect stamen to a simple, more or less amorphous gland. We have seen that, in Claoxylon, one species, C. sandwicense, affords equally direct evidence of the same transition. Direct testimony to this effect is not very often met with in Erythrococca, but indirect evidence as to the staminodial character of these glands is by no means wanting. Cases of this are encountered in the section Adenoclaoxylon. In E. Kirkii, where the extrastaminal glands are usually connate in an urceolum, we find no very definite indication of the staminodial nature of the glands, but in E. mitis, where these glands are free, they are frequently thickened and 2-lobed, and much resemble imperfect stamens. In E. bongensis and $E$. rigidifolia, where the extrastaminal ring met with in E. Kirkii and $E$. mitis does not occur, the stamens of the outermost series have each a pair of minute glands adnate to the base of the filaments. In E. Paxii, where there is usually an extrastaminal ring which is incomplete, some at least of the stamens exhibit the same association with a pair of receptacular glands. ${ }^{3}$ The meaning of the arrangement becomes apparent in E. olacifolia, where there is an extrastaminal ring which is usually complete, but where, when the ring is incomplete, a missing gland may be replaced by a perfect stamen. The glands of the extrastaminal ring are usually considerably larger than the interstaminal glands of the same species, and may reasonably be interpreted as representing a fused pair of basal glands belonging to a stamen which is itself suppressed. This interpretation is more or less confirmed by the arrangement met with in E. subspicata, where the extrastaminal ring consists of twelve glands agreeing in shape and size with the interstaminal ones, but united at their bases as six 'pairs' of glands,

1 The function of these viscid hairs, among which, in open flowers, insects are occasionally found entangled, calls for more attention in the field than it has so far received.

${ }^{2}$ In the cases of Adenoclaoxylon and Athroandra, which immediately concern us since both are now transferred to Erythrococca, and again in the case of Discoclaoxylon, Mueller avoids the use of the term 'disc'. But the 'urceolum' spoken of under Adenoclaoxylon and Athroandra and the 'urceolate ring of glands' described under Discoclaoxylon are definitely referred to under Gymnoclaoxylon as 'an extrastaminal disc' and under Euclaoxylon as a 'disc surrounding the receptacle'. Mueiler, however, does not employ the term ' disc' in connexion with the interstaminal glands, which differ from the extrastaminal ones in situation, but do not differ from them in character.

3 This is well shown by Rendle in Journ. Linn. Soc. Bot., xxxvii, t. 3 , fig. 5 . 
the 'pairs', however, remaining perfectly distinct. The interstaminal glands throughout the genus are remarkably uniform ; they are rhomboid and truncate or subtruncate at the apex where the viscid long hairs arise, and show no clear indication of their staminodial character. The chief deviation from this shape is in E. zambesiaca and E. natalensis, where the glands are flattened, suborbicular, and fringed with marginal short hairs; here, again, there is no indication that the glands are modified stamens. But there is another deviation from the rhomboid form which, though less marked, is more interesting. A few species in various sections, such as E. rigidifolia in Adenoclaoxylon, E. Menyharthii in Trichogyne, E. polyandra in Pseudathroandra, and E. Molleri in Chloropatane, have glands that are ovoid instead of rhomboid, and are then glabrous or nearly so. In the cases of $E$. rigidifolia, $E$. polyandra, and $E$. Molleri, where the glands are all interstaminal, they are not all sessile; some of the glands are distinctly stipitate and have all the appearance of being rudimentary stamens. In the case of $E$. Menyharthii, Brown has, indeed, interpreted the glands, which are all extrastaminal, as staminodes (Kew Bull., I 909, I4I).

The word 'disc', in connexion with the female flower, has the sanction of general use and common consent ; it is, however, doubtful if the term be more satisfactory there than it is in the case of the male. The hypogynous scales of which this 'disc' is composed in the sub-genus Euerythrococca are invariably discrete, but in Athroandra either are so large as to be contiguous under the base of the ovary or are connate in a lobed, rarely a subentire, shallow cup. The Euerythrococca arrangement is that which is met with in the genus Micrococca, and Hooker has entered a plea for caution in connexion with this group (Flor. Brit. Ind., v. 410), which deserves careful attention. Hooker has, indeed, tentatively suggested that the scales may perhaps be petals ; their usual appearance and the circumstance that, as a rule, they alternate with the calyx-segments lend support to this view. But it has to be noted that they also alternate with the carpels, ${ }^{1}$ and although, as a rule, the carpels are isomerous with and opposite to the calyx-segments, cases are by no means rare in which the carpels are fewer than the calyx-segments. When the number of carpels is thus reduced, there is a corresponding reduction in the number of hypogynous scales; this is not what might be anticipated, as an invariable occurrence, had the scales been modified petals. There is thus room for an alternative suggestion;

\footnotetext{
1 An indication that this interpretation is not wholly satisfactory is afforded by the arrangement met with in Claoxylon § Discoclaoxylon, Muell. arg. In this case the female calyx, like the male calyx, is uniformly 4-partite. The ovary is always 2-locular; the disc consists of two very large, fleshy, reniform scales, alternate with the carpels and prolonged under the base of the ovary so that their edges are contiguous both in front and behind, as in the species of Athroandra § Hemierythrococca. In Discoclaoxylon, however, while the carpels are exactly opposite the anterior and the posterior calyx-lobes, the hypogynous scales, instead of alternating with a pair of calyx-lobes, are opposite the two calyx-lobes which constitute the lateral pair.
} 
the scales may perhaps represent a modified androecium. That this suggestion is, at least sometimes, more satisfactory than the other, may be gathered from an examination of the arrangement which obtains in the plant on which the genus Poggeophyton, Pax (Engl. Bot. Jahrb., xix. 88), was based. This plant agrees with Erythrococca in having perulate buds, stipular thorns, and plumosely laciniate stigmas. It was believed, when the genus was proposed, that it differs from Erythrococca as regards its fruit. This, as we now know, is not the case; the difference between Poggeophyton aculeatum and an Erythrococca, such as E. aculeata, is confined to the hypogynous 'disc'. That difference is certainly striking. In Erythrococca the 'disc' is composed of small, flattened discrete scales, isomerous and alternate with the carpels. In Poggeophyton these hypogynous scales are replaced by large staminodes, isomerous and alternate with the carpels; what Pax treats as the 'disc' is a ring of smaller oblong glands hirsute at their tips with long viscid hairs. The glands which constitute this ring are sometimes free, sometimes slightly connate below, and belong to a whorl external to that in which the staminodes are situated. The staminodes are obviously only somewhat imperfect stamens with stout cylindric-clavate filaments longer than the anthers; the anther cells are two in number, erect, free except at the base, and without pollen. The 'glands', on the other hand, are identical in appearance and character with the glands that form the extrastaminal 'ring' or the extrastaminal 'urceolum' in the male flowers of an Adenoclaoxylon, such as E. Kirkii or E. mitis, or of a Deflersia, such as E. abyssinica, E. aculeata, or E. subspicata.

The difficulty presented by the conditions described is not, therefore, so formidable as it at first appears. The 'staminodes' of Poggeophyton aculeatum are identical in appearance as well as in position with the hypogynous scales of Claoxylon triste as described by Mueller (DC. Prodr., xv. 2, 779), and with those of $C$. Menyharthii, Pax, except that in C. triste and C. Menyharthii these scales are merely cylindric-clavate filaments which are not surmounted by empty anther cells. Moreover, in C. Menyharthii, apparently as a casual abnormality, one or two small, linear-oblong, glabrous glands may occasionally be met with in addition to the staminodial hypogynous scales, though these glands are less conspicuous than the corresponding ones in Poggeophyton aculeatum, and do not, as in that species, form a complete hypogynous ring.

Two other species, which also are confined to West Central Africa, agree in general facies with Poggeophyton aculeatum, and are evidently members of the same natural group ; in both of these species, however, the staminodes characteristic of $P$. aculeatum are replaced by ovate, subacute, flattened hypogynous scales of the normal Erythrococca type. One of the species, E. Laurentii, is readily distinguished from the others by having leaves of a different shape with shorter and stouter petioles, but the second, 
E. subspicata, resembles Poggeophyton aculeatum so closely that, apart from its 'disc', it is mainly separable because its leaves are denticulate in place of crenate. This fact induces, therefore, some doubt as to whether the presence of receptacular glands of a male type in the female flowers of $P$. aculeatum be more than an abnormality. That doubt is increased by the circumstance that one of Pogge's specimens exhibits an unusual irregularity; towards the base of some of its subspicate racemes, male flowers occupy the positions which higher up the spikes are occupied by ripe fruits. ${ }^{1}$ These male flowers, except that they have 9 stamens instead of 12 , and 5 pairs of extrastaminal glands in place of 6 , are remarkably like the male flowers of $E$. subspicata. It may be argued that this monoecious condition affords an additional reason for treating Poggeophyton aculeatum as the type of a distinct genus. The argument would, however, be open to serious objection; the male flowers in question, in place of being glomerulate, are solitary as if they were female ones. The inference, therefore, rather is that the female flowers exhibit, in the androecial aspect which has been imparted to their ' disc', a complementary effect of the male influence in the plant. All that its characters justify us in concluding is that the particular plant from which Pogge's specimens were taken did not show that clearly defined diclinism which is characteristic of the genus to which it belongs. ${ }^{2}$ The character of the disc in Poggeophyton aculeatum, in place of affording a criterion of generic import, supplies one that is doubtfully adequate for specific discrimination. What, in any case, seems clear, is that the claim of Poggeophytum aculeatum to a place, along with E. subspicata, in the genus Erythrococca, widened as Pax has widened it, is valid.

The fact that in E. Poggeophyton, E. Menyharthii, and E. tristis, the bodies which occupy the position of the flattened hypogynous scales met with in other nearly allied species are manifestly staminodes, while the scales which may accompany these staminodes in E. Poggeophyton and E. Menyharthii are comparable with male receptacular glands, themselves certainly staminodial, appears to warrant the belief that the hypogynous scales in the genus as a whole correspond morphologically with a modified androecium. Whether this interpretation be justified or not, the existence of the conditions that obtain in Claoxylon Menyharthii and in Poggeophyton

1 The only instance in which a doubt has hitherto arisen as to whether a species of Erythrococca may be monoecious, has been in the case of Claoxylon (Athroandra) Schiveinfurthii, Pax (Engl. Bot. Jahrb., xix. 86), a plant which in this paper is treated as a form of C. Aaccidum, Pax. The circum. stances have been fully explained by $\operatorname{Pax}(1$. c.). In the case of $C$. Schweinfurthii, the two sexes are met with in specimens issued by Schweinfurth under the same field number; the presumption therefore is that they may have been found on one plant. But in this instance the male and female flowers are on distinct twigs, and we do not have the definite proof which Poggeophyton aculeatum affords as to the existence of a monoecious condition.

2 Analogous instances of collateral manifestation of the male influence in a female flower and vice versa are not infrequent in Cannabis sativa; an account of some of these may be found in Sc. Mem. by Officers, Med. and Sanit. Dept. India, N.S., no. I 2 , I904. 
aculeatum assists us in interpreting the three types of 'disc' met with in the female flowers of Erythrococca. From a condition such as that occasionally seen in Claoxylon Menyharthii, in which the hypogynous bodies alternating with the carpels are staminodes which are accompanied by an incomplete ring of small free scales, to a condition in which these additional scales fuse with the adjacent staminodes to form as many discrete flattened hypogynous scales as there are carpels, is only a step. From a condition such as that characteristic of Poggeophyton aculeatum, in which the hypogynous bodies alternating with the carpels are staminodes which are accompanied by a complete ring of small free scales, to a condition in which these accessory scales fuse with the adjacent staminodes to form as many contiguous flattened hypogynous scales as there are carpels, is again only a step. From this latter condition to one where these contiguous glands are fused in a complete urceolate 'disc' is but another step in the same direction. That this may have been the history of the evolution of the 'disc' in Erythrococca is suggested by another consideration. In E. africana the disc at first is complete and entire ; in fruit it is distinctly subequally 5 -lobed; the number of lobes suggests the possibility of some relationship to the fact that in the male flowers there are so stamens in the outermost (marginal) series. Another species where there is the suggestion of a similar retrogression is $E$. Molleri; here the 'disc' in the female flower sometimes consists of two free scales with contiguous margins, sometimes is complete; when it is complete this disc at first has a uniform, even or 2-lobed margin, later on it splits along the edge into a number of crenulate lobules.

\section{SUMMARY.}

The result of a detailed consideration of the characters exhibited by these various groups of species with anther cells that remain erect even when empty, is to confirm the conclusion to which Bentham came in 1849 : Erythrococca, Benth., and Micrococca, Benth., though very closely allied to Claoxylon, A. Juss., are easily distinguishable and natural genera. But while Bentham's instinct was in each case right, neither genus is monotypic, as he believed them to be; to Hooker we are indebted both for one of the criteria which enable us to distinguish Erythrococca from its two allies, and for the demonstration of the fact that Micrococca is wider in its limits than Bentham supposed. For the proof of the necessity for an enlargement of the limits of Erythrococca we are indebted to Pax. The characters which enable us to discriminate the three genera may be summarized as follows:-

I. Erythrococca, Benth. ampl. Buds perulate. Racemes interrupted or uniformly floriferous. Capsule subglobose or didymous, coriaceous ; cocci dehiscing loculicidally: subdivided into :- 
I. Euerythrococca. ${ }^{1}$ Stigmas plumosely laciniate or at least incised lobulate.

2. Athroandra, Hook. f. Stigmas entire.

II. Claoxylon, A. Juss. Buds not perulate. Racemes uniformly floriferous. Capsule subglobose, coriaceous; cocci dehiscing loculicidally: subdivided into :-

I. Euclaoxylon, Muell. arg. ${ }^{2}$ Male flowers with only interstaminal glands.

2. Discoclaoxylon, Muell. arg. Male flowers with only an extrastaminal urceolum.

III. MicrococCA, Benth. ampl. Buds not perulate. Racemes interrupted. Capsule deeply 3 -coccous, thinly crustaceous; cocci dehiscing both septicidally and loculicidally.

The necessity for some modification of view as regards the limitation of Micrococca, Benth., was impressed on Sir J. D. Hooker when engaged in the task of dealing with the Indian species of the genus Claoxylon. The necessity for a corresponding modification of view as regards the limits of Erythrococca, Benth., has been similarly impressed upon the writer while occupied in the preparation, at the request of Sir W. T. Thiselton-Dyer, of an account of the African species from time to time referred to Claoxylon, for the 'Flora of Tropical Africa'. The extension of the limits of Micrococca, which Hooker has shown to be essential, and the corresponding extension of Erythrococca, for which we are similarly indebted to Pax, to which effect is here given, departs from the treatment proposed by these authors only in that Micrococca, looked upon by Hooker as a section of Claoxylon, is here considered a distinct genus, while the genus Erythrococca is made to include, besides the section Adenoclaoxylon, also the section Athroandra.

The action here taken involves, therefore, some modification of the estimate hitherto formed with regard to the dimensions of the genus Claoxylon. The restriction of this latter genus is, however, to a certain extent compensated for by the fact that these transfers simplify materially our conception of its geographical distribution. Micrococca, which up to 1887 was believed to be monotypic, is now known to include eight distinct species and one recognizable variety, and to extend from South-East and East Africa and the Comoro Islands to South-West Peninsular India and Ceylon, with one of the species, which is a tropical field-weed, further spread throughout the greater part of Tropical Africa, Southern Arabia, the greater part of India, Western Indo-China, and the Malay Peninsula. Erythrococca, which up to 1894 was also believed to be monotypic, is now known to include over forty recognizable forms, all of them confined to the

1 This sub-genus, as already explained, includes Adenoclaoxylon, Muell. arg.

2 This sub-genus, as already explained, includes Gymnoclaoxylon, Muell. arg. 
African continent or to the islands in the Gulf of Guinea, save one which extends from Abyssinia to Southern Arabia.

Claoxylon, on the other hand, which in 1866 , when allowance has been made for the removal of Adenoclaoxylon, Athroandra, and Micrococca, was believed to contain thirty species, is now known to include about forty-five distinct forms, of which only three are African. The others are natives of the Mascarene Islands (fifteen), South-Eastern Asia (fourteen), Polynesia and New Caledonia (nine), and Australia (four). The three African species belong to an endemic section, Discoclaoxylon, so distinct that no harm could result were it treated as a different genus. A fourth African species, C. sphaerocarpum, Kuntze (Rev. Gen. Plant., iii. 2, 248), has indeed been described from South Africa. The material on which this species is based we have had no opportunity of seeing. Its author has indicated that this material is incomplete; from the careful description which Kuntze has provided it is, however, almost certain that the plant in question belongs to another genus, and there is no evidence that any species belonging to Claoxylon proper, as originally defined by A. Jussieu, occurs on the African continent.

As the whole of the species included in Micrococca and Erythrococca have been described elsewhere, all that seems called for here is a revised. definition of each of these genera, modified in accordance with existing knowledge and supplemented with a systematized enumeration of the forms that appear referable to each. In consequence of the fact that, of the two, Erythrococca-the inclusion of which in Claoxylon has never been proposed -is more closely related to Claoxylon than Micrococca is, it is desirable to reverse the order of their presentation. The enumerations themselves are based on an examination of the material of both genera preserved in the herbaria at Kew, the British Museum, and Berlin, with, in addition, in the case of Erythrococca, the material in the herbaria at Brussels and Paris; in the case of Paris the African collections of Dr. Chevalier have also been available. The specimens of Erythrococca in the post-Prodromus collection of the de Candolle herbarium and in the herbarium of the Natal Botanic Garden have also been studied, as have the specimens, illustrating both genera, collected by Dr. Schweinfurth, which are preserved in the Boissier herbarium. To his friends Dr. Rendle, Professor Engler, Professor De Wildeman, Professor Lecomte, Mr. de Candolle, Mr. Medley Wood, and Mr. Barbey, the writer is deeply indebted for the kind help thus afforded. $\mathrm{He}$ is further greatly indebted to his friends Professor Schinz and Professor Briquet for permission to study the types of Claoxylon Menyharthii, which is preserved in the Zurich herbarium, and of Trewia? africana, which is preserved in the De Lessert herbarium. 


\section{ErythrococcA, Benth. ampl.}

Erythrococca, Benth. in Hook., Niger Fl., 506 (1 849); Baill., Étud. gén. Euphorb., 437, t. 21, f. I0 (1858) et in Adansonia, i. 7 I (1860); Muell. arg. in DC. Prodr., xv. 2, 790 (1866) ; Benth. in Benth. et Hook. f. Gen. Plant., iii. 308 (1 880); Pax in Engl. \& Prantl, Nat. Pflanzenf., iii. 5, 48, fig. 29 A (1890) necnon, sensu ampliore, in Engl. Bot. Jahrb., xix. 87 (1894), et in Engl. Pflanzenw. Ost-Afrik., C, $23^{8}$ (1895).

Adelia, Juss. ex Poir. in Encyc. Meth. Suppl., i. I32 (1810); A. Juss., Tent. Gen. Euphorb., 32, pro parte: Claoxylo quam Adeliae affinior (1824): nec Linn.

Trewia, Baill., Adansonia, i. 68, pro parte et dubitanter (1860): nec Linn.

Mercurialis, Baill., Adansonia, iii. 176 , sensu ampliore (1862) et in Hist. des Plantes, v. 210, sensu ampliore (1874); Deflers, Voy. Yemen, 203, dubitanter (1889): nec Linn.

Claoxylon \$ Athroandra, Hook. f. in Journ. Linn. Soc. Bot., vi. 21 (1862); Muell. arg. in DC. Prodr., xv. 2, 776 (1866); Pax in Engl. \& Prantl, Nat. Pflanzenf., iii. 5, 48, sphalm. Arthroandra (I890): nec Claoxylon, A. Juss.

Claoxylon § Adenoclaoxylon, Muell. arg. in Flora, xlvii. $43^{6}$ (1864), et in DC. Prodr., xv. 2, 775 (I866); Pax in Engl. \& Prantl, Nat. Pflanzenf., iii. 5, 48 (1890): nec Claoxylon, A. Juss.

Deflersia, Schweinf. ex Penzig in Atti Congr. Bot. 1892, Genova, 359 (1893), et in Abhandl. Akad. Berlin, xxxiii. 663, 667, 708: Abyssin. Pflanzennam., I7, 21, 62 (1893): nomen tantum.

Poggeophyton, Pax in Engl. Bot. Jahrb., xix. 88 (1894).

Chloropatane, Engl. in Engl. Bot. Jahrb., xxvi. $3^{83}$ (1899); Perkins \& Gilg in Engl. Pflanzenr. : Monim. 24 (1901); Wright in Thiselton-Dyer, Flor. Trop. Afr., vi. I, I68 (I909).

Rivinoides, Afzel. in sched.: nomen tantum.

Flores dioici vel rarissime forsan casu monoici, apetali. or Calyx membranaceus in alabastro saepissime subglobosus apice minute apiculatus, raro conico-pyramidalis, primum clausus, sub anthesi valvatim 3-4-partitus, casu 5-partitus. Stamina definita vel indefinita (2-64), in receptaculo plus minusve elevato centralia, saepe pluriseriata, glandulis rhombeis subovoideisve vel rarissime complanatis saepissime inter se liberis et apice pilis viscidulis plerumque praelongis onustis consociata; filamenta nunc antheris manifeste longiora, nunc perbrevia antherisque breviora; antherae 2-loculares; loculi obovoidei vel subglobosi, basifixi, erecti, praeter basin inter se liberi, extrorsim rimosi; glandulae plerumque totum receptaculum tegentes et 
inter bases filamentorum dispersae vel per paria basibus ipsis affixae, rarissime circa bases in annulum vel urceolum extrastaminalem tantum dispositae, saepe tamen utroque modo simul in floribus evolutae. Rudimentum ovarii nullum. \& Calyx plerumque 2-partitus, nonnunquam 3 -partitus, rarissime 4-partitus, lobis quam in mare saepius minoribus. Ovarium glabrum vel nonnunquam strigosum, 2-3-loculare; loculi laciniis calycis oppositi vel iis pauciores; ovula in quoque loculo solitaria; stigmata loculis ovarii isomera; nunc elongata, linearia, patula, a basi libera totaque saepissime plumoso-laciniata, raro laevia ; nunc brevia vel brevissima, ovatolanceolata vel suborbicularia, divaricata vel suberecta, subsessilia et basi connata vel in apice styli saepius brevis raro plane evoluti columnaris insidentia, laevia vel perraro papillosa, margine integra vel rarissime incisolobulata. Discus hypogymus e squamis complanatis vel rarissime cylindricoclavatis staminodiiformibus et interdum glandulis minoribus eis maris extrastaminalibus conformibus in serie exteriore additis, majoribus semper cum carpidiis alternantibus eisque isomeris compositus ; squamae nunc inter se liberae et saepissime plane discretae, rarius marginibus contiguae; nunc in urceolum plus minusve annularem margine lobatum vel rarissime subintegrum zygomorphon vel perraro eccentron connatae. Fructus capsularis ; capsula plerumque 2-cocca, didyma, sed saepe 3 -cocca, vel nonnunquam casu abortuque monococca; cocci subglobosi, coriacei, extra glabri vel nonnunquam setosi, loculicide 2-valvi; valvae subreflexae cum columella subspathulata coriacea stigmatibus marcescentibus coronata diu cohaerentes, nonnunquam tamen demum deciduae semina columellamque relinquentes. Semina fere sphaerica, arillo carnoso viscido laete colorato involuta: testa crustacea, foveolato-reticulata; albumen carnosum; embryo axilis; radicula conica vel subcylindrica; cotyledones lati, complanati, suborbiculares.Frutices glabri vel plus minusve puberuli vel pubescentes; inermes vel armati; cortex lenticellatus. Gemmae perulatae; squamae subcoriaceoscariosae, nitidae, saepissime diu persistentes. Folia decidua, alterna, breviter sed distincte petiolata, membranacea, margine glandulosa, crenata vel dentata; petioli supra canaliculati; stipulae coriaceae vel cartilagineae, glabrae, nitidae; nunc minimae, hyalino-scariosae, immutatae; nunc accrescentes et in mamillas vel umbones vel aculeolos conicos rectos hamatosve mutatae, nonnunquam spinulas basi dilatatas apice pungentes efficientes. Flores parvuli vel minuti, in glomerulos axillares sessiles pedunculatosve aggregati, vel secus rhachides racemorum laxorum vel congestorum nonnunquam spiciformium axillarium fasciculatim vel singillatim dispositi. Racemiglomerulive fasciculati vel solitarii; pedunculi graciles; bracteae parvae; pedicelli capillares prope vel raro paulo ultra basin articulati; bracteolae minutae. Bracteae maris saepissime pluriflorae, raro I-florae; feminei plerumque I-florae, raro 2-3-florae. 


\section{Clavis SPECIERUM GREGATIM CONIECTARUM.}

Stigmata plumoso-laciniata vel inciso-lobulata; squamae hypogynae liberae, discretae [I. Euerythrococca] :-

Flores glomeratim congesti ; stipulae aculeolatae [\$ I. Adenoclaoxylon]:Rhachides pubescentes:-

Stamina 6-8

Stamina 9-1 5

Rhachides glabri
9 $\mathbf{r}$. Mites (spp. I, 2).

I 2. Rigidifoliae (spp. 3-5).

ब1 3. 'Fischerianae' (spp. 6, 7).

Flores racemosi :-

Stipulae aculeolatae vel pungentes :-

Stamina glandulis juxtastaminalibus intermixta et simul glandulis extrastaminalibus circumcincta [ $[$ 2. Deflersia]:-

Racemi foliis breviores:-

Ovarium glabrum :-

Stipulae aculeolatae; stamina 6-8 T. Eudeflersieae (spp. 8, 9).

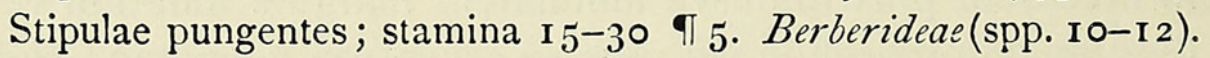

Ovarium strigosum

Racemi foliis subaequilongi
91 6. 'Aculeatae' (sp. 13).

Tा 7. Subspicatae (spp. I4-16).

Stamina aut glandulis extrastaminalibus circumcincta aut glandulis

juxtastaminalibus intermixta: glandulae nunquam

in utroque modo simul in floribus evolutae; ovarium dense

strigosum $\left[\S_{3}\right.$. Trichogyne $]$ :-

Glandulae receptaculares omnes extrastaminales; squamae hypogynae staminodiiformes

ๆ 8. Tristes (spp. I7, I8).

Glandulae receptaculares omnes juxtastaminales; squamae hypogynae complanatae

9 9. Lasiococcae (spp. 19-23).

Stipulae immutatae $\left[\S_{4}\right.$. Pseudathroandra] I 1 o. Pauciflorae (spp. 24, 25).

Stigmata integra; stipulae immutatae [II. Athroandra]:-

Stigmata a basi libera ; squamae hypogynae liberae sed circa basin ovarii marginibus contiguae $[\S 5$. Hemierythrococca $]$ :-

Filamenta antheris longiora

Filamenta antheris breviora

T I I. Membranaceae (sp. 26).

T1 1 2. Patulae (spp. 27, 28).

Stigmata basi connata vel in apice styli insidentia; squamae hypogynae fere semper in urceolum connatae [ $\$ 6$. Chloropatane $]$ :-

Stylus subnullus:-

Stigmata suborbicularia, majuscula, suberecta

Stigmata ovato-lanceolata, divaricata

TI 13. 'Rivinoides' (spp. 29-3I). I1 4 . Rivulares (sp. 32). 
Stylus distinctus :-

Stigmata suborbicularia, minima, suberecta, stylo columnari multo breviora TI 5. Columnares (spp. 33-35).

Stigmata ovato-lanceolata, sub anthesi divaricata demum recurva, stylo abbreviato longiora I 16 . Oleraceae $\left(\mathrm{sp} \cdot 3^{6-42}\right)$.

\section{Subgen. I. EUERYTHROCOCCA.}

Erythrococca, Benth.; Baill.; Muell. arg.; Pax; 1l. supra cit. Adelia, Juss.; A. Juss. ; 11. supra cit. Mercurialis, Baill., pro parte ; Deflers ; 11. supra cit. Claoxylon $\S$ Adenoclaoxylon, Muell. arg.; loc. supra cit. Deflersia, Schweinf.; loc. supra cit. Poggeophyton, Pax; loc. supra cit. Claoxylon $\S$ Athroandra, Muell. arg., pro parte; loc. supra cit.: nequaquam $\S$ Athroandra, Hook. f.

Stipulae plerumque accrescentes, induratae, mammillas umbones aculeolos vel spinulas efficientes; rarissime immutatae. Flores plerumque minuti in glomerulos vel racemos dispositi. Stamina saepissime definita et nisi in E. Menyharthii glandulis juxtastaminalibus consociata, saepe simul glandulis extrastaminalibus circumcincta; filamenta antheris longiora; antherarum locelli subglobosi, rarius obovoidei. Ovarium glabrum vel strigosum; stigmata nisi in E. polyandra sessilia, libera, patula, a basi tota plumosolaciniata-in $E$. polyandra stigmata in apice styli brevis insidentia, divaricata, margine inciso-lobulata. Discus hypogynus e squamis complanatis vel raro cylindrico-clavatis staminodiiformibus cum carpidiis alternantibus eisque isomeris rarissime alteris minoribus seriei extrastaminodialis additis compositus; squamae inter se liberae et minoribus neglectis plane discretae.

$\S$ I. Adenoclaoxylon. Flores minuti in glomerulos axillares congesti. Stamina definita vel subdefinita glandulis juxtastaminalibus intermixta et saepe simul glandulis extrastaminalibus - his tamen nonnunquam plus minusve imperfectis-circumcincta ; antherarum locelli subglobosi. Ovarium nisi in E. olacifolia glabrum vel raro pilis setosis paucis onustum -in E. olacifolia dense strigosum ; squamae hypogynae complanatae, inter se discretae. Perulae persistentes. Stipulae mammillas umbones vel aculeolos efficientes.

I I. Mites. Glomeruli sessiles; rhachides pubescentes. Stamina saepissime 8 ; glandulae hirsutae, extrastaminates annulum vel urceolum perfectum efficientes. Ovarium glabrum. Stipulae in mammillas vel umbones tantum mutatae.-Claoxylon \$ Adenoclaoxylon, Muell. arg. in Flora, xlvii. 436 (I 864) : sensu stricto.

1. E. Kirkii. Folia tenuia. Pedicelli masculi flaccidi, flexuosi. Glandulae extrastaminales saepissime in urceolum connatae.-E. mitis, Pax in Engl. Bot. Jahrb., xxiii. 524; partim et quoad spp. Stuhlmanniana apud Dar-es-Salam lecta (1897); vix Pax in Engl. Pflanzenw. Ost-Afrik., C. 
Claoxylon Kirkii, Muell. arg. in Flora, xlvii. $43^{6}$ (1864), et in DC. Prodr., xv. 2. 776 (1866); Pax in Engl. Pflanzenw. Ost-Afrik., C, 238 (1895); Sim in Flor. Port. E. Afr., 105 (I g09).

[VIII a.] EAST AfRICA: Miozambique. Portuguese East Africa : coast near Beira, Schlechter! Coast near Mozambique, Stuhlmann 397 !

[VIII b.] EAST AFrICA : Zanzibaria. German East Africa: Lindi ; Rovuma Bay, Kirk! Sim. Dar-es-Salam; Kodenga, Stuhlmann 6369! Kinda, Stuhlmann 65II! Dar-es-Salam, Stuhlmann 7506! $7555 ! 7595$ ! 7649! Bagamoyo; Bagamoyo, Stuhlmann 254! 7233! 7266! Tanga ; Amboni, Holst 2709! British East Africa: Seyidieh; Mombasa, Boivin! Hildebrandt 2039 !

This species, the basis of Mueller's section Adenoclaoxylon, has only been collected on or near the coast.

2. E. mitis, Pax in Engl. Pflanzenw. Ost-Afrik., C, 238 (1895). Folia firmula. Pedicelli masculi rigidiusculi, stricti. Glandulae extrastaminales saepissime liberae.-Pax in Engl. Bot. Jahrb., xxiii. 524 quoad spp. Volkensiana tantum (1897), et in Engl. Bot. Jahrb., xxx. 339 (I901).

[VIII b.] EAST AFRICA : Zanzibaria. German East Africa: Morogoro; Khutu Steppe, Goetze 105! Tanga; between Magila and Sega, Volkens 72 !

Nearly allied to $E$. Kirkii and perhaps an inland form of that species, as Pax has suggested, but readily distinguishable by the firmer leaves, shorter stiffer male pedicels, and smaller thicker calyx-lobes.

2. Rigidifoliae. Glomeruli sessiles vel pedunculati; rhachides pedunculisquepubescentes. Stamina 9-I 5; glandulae glabrae vel raro pilis perpaucis onustae; extrastaminales annulum perfectum vel incompletum efficientes, vel obsoletae. Ovarium glabrum vel strigosum. Stipulae manifeste in aculeolos conicos rectos hamatosve mutatae. Folia firmula.

3. E. bongensis, Pax in Engl. Bot. Jahrb., xix. 88 (1894). Glomeruli sessiles. Stamina 9-I2; annulus extrastaminalis incompletus. Ovarium ignotum. Folia plus minusve pubescentia.

[IX.] East Central Africa. German East Africa: Ruanda; Buganza, south of Lake Mohasi, Mildbraed 591 ! Congo State: Eastern Prov.; Rutschuru Steppe, Mildbraed 1874! Southern Sudan : Bahr-et-Ghazal ; Bongo, Gurfala, Schweinfurth 2226 (Hb. Berlin)! 2296 (Hb. Kew)!

A very distinct species.

4. E. rigidifolia, Pax in Engl. Bot. Jahrb., xliii. 320 (1909). Glomeruli pedunculati. Stamina 9-I5; annulus extrastaminalis obsoletus. Ovarium glabrum vel parce pilosum. Folia glabra vel parce pubescentia. 
[IX.] East Central Africa. German East Africa: Bukoba; Karagwe, 4,000-6,000 ft., Stuhlmann 1760! Scott Elliot 8159! Ruanda; Mugarura Island in Lake Kiwa, Mildbraed III2, Congo State: Eastern Province; north shore of Lake Albert Edward, 2,700 ft., Mildbraed I935! Uganda: Western Prov.; Unyoro, Kaichura on east side of Lake Albert Nyanza, Scott Elliot 8033 (a stunted form with small leaves)! Uganda Prov.; marsh to the west of Lake Victoria Nyanza, Scott Elliot 7449 ! British East Africa: Naivasha; Nakuro, 6,000 ft., Scott Elliot 6793! Ukamba ; Nairobi, Linton I59! Duruma, Kassner 301 !

Very nearly allied to $E_{0}$ bongensis, from which it differs mainly in having the glomerules shortly peduncled, and in having usually larger leaves, though in the case of Scott Elliot 8033, from Unyoro, the leaves are no larger than in E. bongensis. The flowers only differ in that there is no trace of an extrastaminal ring of glands in E. rigidifolia.

5. E. olacifolia, Prain in Kew Bull. IgII, 89 (IgII). Glomeruli pedunculati. Stamina I2; annulus extrastaminalis plerumque perfectus. Ovarium dense adpresse strigosum. Folia glabra.

[IX.] East Central Africa. Uganda: Western Prov.; Toro, Bukarungu, 2,900 ft., Bagshawe II9I!

Closely allied to $E$. rigidifolia, but readily distinguished by the longer petioles, the strigose ovary, and the sparingly setose capsule. The extrastaminal ring of glands is usually complete; sometimes a gland may be absent or replaced by a stamen. The hypogynous scales are large, prominent, and almost staminodial, their tips reaching the bases of the stigmas.

9 3. 'Fischerianae.' Glomeruli pedunculati; rhachides pedunculisque glabrae. Stamina IO-2I ; glandulae parce hirsutae, extrastaminales annulum incompletum vel perfectum efficientes. Ovarium glabrum. Stipulae manifeste in aculeolos conicos rectos hamatosve mutatae. Folia tenuia.

6. E. Paxii, Rendle in Journ. Linn. Soc. Bot., xxxvii. 2 I 2, t. 3 (1905). Pedunculi glomerulis vix longiores. Stamina I 5 vel 18 vel $2 \mathrm{I}$; annulus extrastaminalis saepissime incompletus.

[IX.] East Central Africa. German East Africa: Kilimanjaro; Marangu, 5,000 ft., Volkens 2354! Uganda: Western Prov. ; Ankole, near the River Rufúa, Bagshawe 5'3!

Very nearly allied to $E$. Fischeri, from which it differs mainly in the shorter peduncles and the more numerous stamens, the latter surrounded by only an imperfect ring of glands.

7. E. Fischeri, Pax in Engl. Bot. Jahrb., xix. 88 (1894). Pedunculi glomerulis longiores; rhachis saepe elongata glomerulum alterum terminalem suffulciens. Stamina IO-I2; annulus extrastaminalis perfectus glandulis 
nonnunquam plus minusve connatis.-Pax in Engl. Pflanzenw. Ost-Afrik., C, 238 (I 895).

[IX.] East Central Africa. German East Africa: without precise locality, Fischer $2 \mathrm{I}$ !

A very distinct species; the elongated rachis with often a second somewhat smaller terminal glomerulus renders this species a connecting link between the sections Adenoclaoxylon and Deflersia.

$\S$ II. Deflersia. Flores saepissime minuti in racemos axillares dispositi; racemi angustiores foliis breviores vel angustissimi spiciformes foliis subaequilongi. Stamina nisi in E. natalensi definita, semper glandulis juxtastaminalibus intermixta et simul glandulis extrastaminalibus circumcincta ; antherarum locelli subglobosi. Ovarium nisi in $E$. anomala glabrum; squamae hypogynae nisi in $E$. Poggeophyto complanatae, inter se discretaein E. Poggeophyto squamae cylindrico-clavatae, stamindiiformes, antheras cassas suffulcientes, glandulis minoribus eas floris masculi simulantibus additis. Perulae persistentes vel deciduae. Stipulae saepe spinulas basi dilatatas apice pungentes, raro umbones vel aculeolos tantum efficientes.

IT 4. Eudeflersieae. Racemi foliis breviores; pedicelli masculi prope basin articulati. Flores minuti; calyx masculus fere ad basin usque partitus. Stamina 6-8; glandulae rhombeae, hirsutae vel glabrae, filamentis breviores. Ovarium glabrum; squamae hypogynae complanatae, inter se discretae. Stipulae in mammillas vel aculeolos conicos mutatae.-Deflersia, Schweinf. ex Penzig in Atti. Congr. Bot. 1892, Genova, 359 (1893): sensu stricto.

8. E. abyssinica, Pax in Engl. Bot. Jahrb., xix." 87 (1894). Folia distincte petiolata. Pedunculi masculi glabri. Calyx masculus 3-partitus. Glandulae receptaculi hirsutae.-Schweinf. in Bull. Herb. Boiss., vii., app. 2, 306 (1 899). Mercurialis? sp., Deflers, Voy. Yemen, 203 (1889). Claoxylon Deflersii, Schweinf. in Pl. Arab. Fel. exsicc. n. 933 (I89I) : nomen tantum. Deflersia erythrococca, Schweinf. ex Penzig in Atti Congr. Bot. 1892, Genova, 359 (1893), et in Abhandl. Akad. Berlin, xxxiii. 663, 667, 708: Abyssin. Pflanzennam. 17, 21, 62 (1893): nomen tantum.

[X.] North-EASt Africa. Abyssinia: Rora, 6,000 ft., Hildebrandt 509! Eritrea: Ghinda, 3,300 ft., Schweinfurth 327! near Felakhit, 3,0003,500 ft., Schweinfurth 2239! near Acrour, 6,300 ft., Schweinfurth \& Riva I037! Mogod Valley, 4,650 ft., Schweinfurth 2059! Gheleb, 5,700 ft., Schweinfurth \& Riva II 32 ! Arabia: Yemen; Mt. Masâr, near Attâra, 6,000 ft., Deflers 4I3; Wadi Madfar; near Hodjela, 2,700 ft., Schweinfurth 933! Wadi Chusiet; near 'Ussil, 4,000 ft., Schweinfurth II76 ; Menacha, 8,000 ft., Schweinfurth 1690! Gebel Bura; above Hille, 3,000ft., Schweinfurth 1813. 
A very distinct species. The Mogod Valley specimens, cited by Schweinfurth as 2058 , but actually numbered (in Herb. Boissier) 2059 , have unusually large leaves, up to $10.5 \mathrm{~cm}$. long by $6 \mathrm{~cm}$. wide; so also have those of 2239 from near Felakhit, which reach a length of $13.5 \mathrm{~cm}$. and are $5^{-6} \mathrm{~cm}$. wide.

9. E. usambarica, Prain in Kew Bull. I9II, 90 (I9II). Folia breve petiolata. Pedunculi masculi pubescentes. Calyx masculus 4-partitus, vel casu 5-partitus. Glandulae receptaculi glabrae.

[VIII b.] EAST AFRICA: Zanzibaria. German East Africa: Tanga ; Derema, Scheffler I60! near Amani, 2,800-3,000 ft., Engler 708! Handai ; Nquelo, 3,000 ft., Heinsen 74!

Nearly allied to $E$. abyssinica, of which it appears to be the East African representative.

T 5. Berberideae. Racemi foliis breviores; pedicelli masculi munc prope basin munc plane ultra basin articulati. Flores parvi vel minuti; calyx masculus ultra medium vel fere ad basin usque partitus. Stamina I5-30; glandulae late ovatae vel oblongae, complanatae, hirsutae, filamentis breviores vel aequilongae. Ovarium glabrum; squamae hypogynae complanatae, inter se discretae. Stipulae in spinulas basi dilatatas apice pungentes mutatae.

10. E. zambesiaca, Prain in Kew Bull. I9I I, 90 (I9II). Folia tenuia. Pedunculi masculi pubescentes. Flores masculi minuti, virides; pedicelli prope basin articulati. Stamina I5 vel I 8 ; glandulae extrastaminales 6 ; juxtastaminales ovatae, filamentis breviores.

[VIII a.] EAST Africa : Mozambique. Nyasaland: Lower Shire ; Chiromo, Scott Elliot 2795 !

A very distinct species.

11. E. natalensis, Prain in Kew̄ Bull. I9I I, 9I (I9II). Folia tenuia. Pedunculi masculi glabri. Flores masculi parvi nec tamen minuti, albi ; pedicelli manifeste supra basin articulati. Stamina 30 ; glandulae extrastaminales Io; juxtastaminales ovatae, filamentis breviores.

[VII b.] South-EAST AfricA: Natal. Inanda; Mt. Edgecumbe, Wood I089! Mt. Moreland, $500 \mathrm{ft}$., Wood I39I! without precise locality, Gerrard 8I !

A very distinct species.

12. E. berberidea, Prain in Kew Bull. I9I I, 92 (I9I I). Folia firmula. Pedunculi masculi glabri. Flores masculi parvi nec tamen minuti, virides ; pedicelli manifeste supra basin articulati. Stamina I 5 vel I 8 ; glandulae extrastaminales 5 ; juxtastaminales filamentis aequilongae. 
[VII b.] South-East Africa: Natal. Near Durban, 200 ft., Wood 7582 ! 9439! II 810!

Very nearly allied to $E$. natalensis, but with thicker leaves, which are different in outline, and with fewer stamens, which are accompanied by different interstaminal glands.

96. 'Aculeatae.' Racemi foliis breviores; pedicelli masculi alte ultra basin articulati. Flores minuti; calyx masculus ad medium usque tantum fissus; tubus campanulatus. Stamina 6-II ; glandulae rhombeae, crassae, hirsutae, filamentis longiores. Ovarium adpresse sirigosum; squamae hypogynae complanatae, inter se discretae. Stipulae in spimulas basi dilatatas apice pungentes mutatae.-Erythrococca, Benth. in Hook., Niger Fl., 506 (1849), et in Benth. et Hook. f. Gen. Plant., iii. 308 (I880): sensu stricto.

13. E. anomala. Glandulae receptaculares majusculae, staminibus antheris haud exceptis aequialtae.-Adelia anomala, Juss. ex Poir. in Encyc. Meth. Suppl., i. I32 (I8Io); A. Juss., Tent. Gen. Euphorb., 32 (I 824). Erythrococca aculeata, Benth. in Hook., Niger Fl., 506 (I849); Baill., Étud. gén. Euphorb., 437, t. 21, f. Io (1858); Muell. arg. in DC. Prodr., xv. 2, 79I (I866) ; Pax in Engl. \& Prantl, Nat. Pflanzenf., iii. 5, 48, fig. 29 A (I890), et in Engl. Bot. Jahrb., xix. 87 (1894). E. aculeata, var. acutissima, N. E. Br. ex Stapf in Journ. Linn. Soc. Bot., xxxvii. II4 (I905), et in Johnst. Liberia, ii. 649 (1906). Mercurialis aculeata, Baill., Adansonia, iii. 173 (1862).

[IV a.] WEST AFRICA: Upper Guinea. Senegambia; neighbourhood of Boquet, Heudelot 856 ! Sierra Leone: without precise locality, Smeathman! Afzelius! Vogel 162! Bagroo River, Mann 879! Scarcies ; near Wallia, Scott Elliot 4790! Limba; Makende, Scott Eliott 5694! Liberia : near Monrovia, Whyte! Ivory Coast: Bouroukrou, Chevalier 16579! Agnichy Valley; Copiekrou, Chevalier I7103! Sassandra; Soubré, Chevalier I7990! Southern Nigeria: Western Lagos, Rowoland! Yorubaland; at Ibadan, Schlechter I30I2! Olokemeji, Foster 285! Cameroons: JohannAlbrechtshohe, Staudt 466 ! Victoria, Winkler II5!

A very distinct species, the original basis of the genus : readily distinguished from every other species by the relatively large receptacular glands and the relatively shorter calyx-lobes. The form described as var. acutissima hardly differs sufficiently to deserve separate recognition. Heudelot notes that this plant is much in request owing to the high reputation in which it is held as a vermifuge.

I 7. Subspicatae. Racemi arcte spiciformes foliis subaequilongi; pedicelli masculi prope basin articulati. Flores minuti; calyx masculus paulo ultra medium fissus; tubus late campanulatus. Stamina 9-12; glandulae oblongae, hirsutae, filamentis aequilongae; extrastaminales per paria inter se libera imo basi connatae. Ovarium glabrum; squamae hypogynae munc complanatae, inter se discretae; nunc staminodiiformes cylindrico- 
clavatae, antheras locellis cassis suffulcientes annuloque glandularum minorum extrastaminodialium eis floris masculi similium circumcinctae. Stipulae in spinulas basi dilatatas apice pungentes mutatae.-Poggeophyton, Pax in Engl. Bot. Fahrb., xix. 88 (1894).

14. E. subspicata, Prain in Kew Bull. 19II, 185 (I9II). Stamina I2. Squamae hypogynae carpidiis alternantes ovato-lanceolatae, complanatae, in memoriam petala reducentes, inter se discretae. Folia distincte petiolata, ovato-oblonga, acuminata, margine denticulata subinde manifeste lobata.E. aculeata, De Wild. \& Dur., Ann. Mus. Congo, Bot., sér. 2, i. 50 (1899), et sér.3, ii. 209 (I90I); Dur., Syll. Flor.Cong., 49 I (I 909), pro parte : nec Benth.

[V.] West Central Africa. French Congo: Oubangi ; Krebedje, Fort Sibut, Chevalier 3617! Congo State: Equatorial Dist.; Coquilhatville, Dervevre 692 !

A very distinct species.

15. E. Laurentii, Prain in Kew Bull. I9II, 186 (IgII). Stamina ignota. Squamae hypogynae carpidiis alternantes ovato-lanceolatae, complanatae, in memoriam petala reducentes, inter se discretae. Folia breve petiolata, ovata, acuta, margine parum crenulata.-E. aculeata, De Wild., Miss. Laurent., I29 (I 905); Dur., Syll. Flor. Cong., 49I (I 909), pro parte : nec Benth.

[V.] West Central Africa. Congo State: Aruwimi ; Lie, Laurent!

Nearly allied to $E$. spicata, but readily distinguished by the differently shaped, smaller leaf-blades and the very much shorter, but at the same time considerably broader and stouter, petioles.

16. E. Poggeophyton, Prain in Kew Bull. I9II, 187(I9II). Stamina 9. Squamae hypogynae dimorphae, alterae carpidiis alternantes staminodiiformes subcylindrico-clavatae apice locellis antherarum cassis indutae, alterae minores glandulas maris receptaculares simillimae annulum exteriorem circa basin ovarii efficientes. Folia distincte petiolata, oblongolanceolata, acuta, margine parum crenulata.-Poggeophyton aculeatum, Pax in Engl. Jahrb., xix. 89 (1894); Dur. \& Schinz, Étud. Flor. Cong., 245 (1896); Engl. in Sitzb. Preuss. Akad. Wiss., xxxviii. 829 (1908); Dur., Syll. Flor. Cong., 490, 656 (1909).

[V.] West Central Africa. Congo State: Kasai ; on the Lulua, Pogge 1370 !

Very near to $E$. subspicala, but distinguishable by the somewhat differently shaped leaves and by the dimorphic hypogynous glands, though it is doubtful whether this latter character may not be an individual instance of abnormality.

$\S$ III. TRICHOGYNe. Flores minuti, in racemos axillares dispositi. Stamina saepissime definita, aut glandulis extrastaminalibus circumcincta aut glandulis juxtastaminalibus intermixta ; glandulae nunquam in utroque 
modo simul in floribus evolutae; antherarum locelli plerumque obovoidei. Ovarium semper dense strigosum; squamae hypogynae nunc cylindricoclavatae staminodiiformes sed anantherae, aliquando glandulis minoribus eas floris masculi simulantibus additis ; nunc complanatae, inter se discretae. Perulae persistentes. Stipulae umbones vel aculeolos efficientes.-Claoxylon $\S$ Athroandra, Muell. arg. in DC. Prodr., xv. 2, 776, pro parte (I866); Pax in Engl. \& Prantl, Nat. Pflanzenf., iii. 5, 48, pro parte (I890) : nec Hook. f.

T 8. Tristes. Pedicelli alte ultra basin articulati. Stamina 2-5, glandulis extrastaminalibus glabris circumcincta; glandulae juxtastaminales o. Squamae hypogynae carpidiis isomerae staminodiiformes subcylindricoclavatae, apice integrae, aliquando glandulis minoribus eas floris masculi simulantibus additis.

17. E. Menyharthii. Pedunculi feminei 2-4-flori-Claoxylon Menyharthii, Pax in Bull. Herb. Boiss., sér. 2, i. 877 (I90I). Claoxylon C. tristi affine, Pax in Baum, Kunene-Sambesi Geb., 283 (1903). C. virens, N. E. Br. in Kew Bull. 1909, I40 (1909).

[VI.] South-West Africa. Portuguese West Africa : Mossamedes ; on the Kwito below its confluence with the Longa, Baum 549! German South-West Africa: Awas Mts., Dinter 808! Bechuanaland: ridge on the north side of Messeringa Vley, Seiner II. 277! Ngamiland: Kwebe Hills, 3,400 ft., Mrs. Lugard 51! Lugard 53! 94! Rhodesia: Mboruma on the Zambesi, Menyharth 889 b!

[IX.] East Central Africa. German East Africa: Magu Kagchi, Fischer 387 !

Very nearly allied to $E$. tristis, of which the male flowers are still unknown. Female specimens of E. Menyharthï can only be distinguished from those of $E$. tristis by having several-flowered racemes instead of solitary flowers.

18. E. tristis. Pedunculi feminei I-flori-Claoxylon triste, Muell. arg. in Journ. Bot., ii. 334 (1864), et in DC. Prodr., xv. 2, 779 (1866); Hiern in Cat. Afr. Pl. Welw., 975 (1900).

[VI.] South-West Africa. Portuguese West Africa: Mossamedes ; Huilla, near Humpata, in rocky places at 5,000 ft., Welwitsch 390 ! Morro de Lopollo, Welwitsch 391 ! Mounyino, 6,000 ft., Antunes 313!

A very distinct species; each female peduncle bears a solitary articulate pedicel.

T 9. Lasiococcae. Pedicelli prope basin articulati. Stamina plerumque 9-15, in specie singula tamen (E. Ledermanniana) 27, glandulis juxtastaminalibus hirsutis intermixta; glandulae extrastaminales o. Squamae hypogynae carpidiis isomerae, complanatae, inter se discretae.

19. E. lasiococca. Stamina I5. Calyx femineus 2-lobus. Folia parva, pubescentia, $0.8-\mathrm{I} \cdot 2 \mathrm{~cm}$. longa; petiolus $3 \mathrm{~mm}$. longus.-Claoxylon lasio- 
coccum, Pax in Engl. Bot. Jahrb., xix. 87 (1894) et in Engl. Pflanzenw. Ost-Afrik., C, $23^{8}$ (1895).

[IX.] East Central Africa. German East Africa: Eastern shore of Lake Tanganyika, Scott Elliot $823 \mathrm{I}$ ! Uganda : without precise locality, Stuhlmann 1484 !

A very distinct species, easily recognized within the group by its small leaves.

20. E. Ledermanniana, Prain in Kew Bull. I9II, 92 (I9II). Stamina 27. Calyx femineus ignotus. Folia glabrescentia, $4-5 \mathrm{~cm}$. longa ; petiolus $6 \mathrm{~mm}$. longus.

[IV a.] West AfRICA: Upper Guinea. Cameroons: Esole; on Mt. Basso, 6,rco ft., Ledermann 2032! Mfongu; Muti slopes, 5,6006,300 ft., Ledermann $5^{877}$ !

Most nearly allied to $E$. Mildbraedii, from which it differs in the shape and pubescence of the leaf, in the shorter petioles, and in the more numerous stamens with considerably longer filaments.

21. E. Mildbraedii. Stamina 9-12. Calyx femineus 2-lobus. Folia pubescentia, $5-7.5 \mathrm{~cm}$. longa; petiolus $\mathrm{I} \cdot 2 \mathrm{~cm}$. longus.-Claoxylon Mildbraedii, Pax in Engl. Bot. Jahrb., xliii. 80 (1909).

[IX.] East Central Africa. German East Africa: Ruanda; Kissenge, 7,600 ft., Mildbraed I452! Uganda: Ruwenzori ; Kivata, 7,0009,000 ft., Scott Elliot 7637!

A very distinct species.

22. E. trichogyne. Stamina ignota. Calyx femineus 2-lobus. Folia pubescentia, 4.5-6.5 cm. longa ; petiolus $3 \mathrm{~mm}$. longus.-Claoxylon trichogyne, Muell. arg. in Journ. Bot., ii. 334 (1864), et in DC. Prodr., xv. 2, 779 (I 866) ; Hiern in Cat. Afr. Pl. Welw., 975 (1900).

[IV b.] West AfricA: Lower Guinea. Portuguese West Africa: Angola ; Golungo Alto, near Sange, Welwitsch 396 !

A very distinct species.

23. E. hirta, Pax in Engl. Bot. Jahrb., xliii. 32 I (1909). Stamina Io. Calyx femineus 4 -lobus, raro 3 -lobus. Folia pubescentia, $5^{-10} \mathrm{~cm}$. longa; petiolus 5-6 $\mathrm{mm}$. longus.

[IX.] East Central Africa. Uganda: Entebbe, 4,000 ft., Bagshawe 793! Ruwenzori ; Butaga Forest, 7,000-8,000 ft., Scott Elliot 7998! Congo State: West Ruwenzori ; Kalange, 3,600 ft., Mildbraed 2486!

Very closely allied to $E$. trichogyne, from which it mainly differs in having more numerous female calyx-lobes.

$\S$ IV. PSEUdATHROANDRA. Flores parvi in racemos axillares dispositi. Stamina definita vel indefinita, glandulis juxtastaminalibus intermixta; 
glandulae extrastaminales $\circ$; antherarum locelli obovoidei. Ovarium glabrum vel fere glabrum; squamae hypogynae complanatae, inter se discretae. Perulae persistentes. Stipulae minutae, scarioso-hyalinae, immutatae.-Claoxylon \& Athroandra, Muell. arg. in DC. Prodr., xv. 2, 776, pro parte (I866); Pax in Engl. \& Prantl, Nat. Pflanzenf., iii. 5, 48, pro parte (I890): nec Hook. f.

9 Iо. Pauciflorae. Folia glabra, juvenilia purpurascentia.

24. E. pauciflora. Calyx maris 4-lobus. Stamina 24 , vel 27 , vel 30 : saepius 27 ; glandulae rhombeae, hirsutae. Stigmata linearia, patula, a basi libera, tota plumoso-laciniata.-Claoxylon panciflorum, Muell. arg. in Journ. Bot., ii. 333 (1864), et in DC. Prodr., xv. 2, 778 (I866); Hiern in Cat. Afr. Pl. Welw., 975 (I900).

[IV b.] West Africa: Lower Guinea. Portuguese West Africa : Cabinda; Chinchoxo, Soyaux 29! Loanda; near Musaque do Sul and above Loanda, Welwitsch 400! near Loanda, Gossweiler 195 ! also without number! Malange, Gossweiler 452! Musaque, near the English Cemetery, Gossweiler I5 5 !

A very distinct species, which combines the stigmas characteristic of an Euerythrococca with the stipules of an Athroandra.

25. E. polyandra. Calyx maris 3-lobus. Stamina 10-13; glandulae ovoideae, glabrae. Stigmata ovato-lanceolata, sub anthesi divaricata demum recurva, in apice styli brevis insidentia, margine inciso-lobulata.-Claoxylon polyandrum, Pax et K. Hoffm. in Engl. Bot. Jahrb., xlv. 327 (1910).

[VIII b.] EAST Africa : Zanzibaria. German East Africa: Wilhelmstal; Kwai, Albers 36! Tanga; Amani, Warnecke 219! Kraenzlin 2182!

In general facies this species most resembles $E$. pauciflora and may perhaps be looked upon as its East African representative. But it approaches the sub-genus Athroandra more closely than $E$. paucifora does; besides having the unmodified stipules of an Athroandra it has stigmas that, but for being incised-lobulate along the margins, resemble those of the species in the group Oleraceae.

\section{Subgen. II. ATHROANDRA.}

Mercurialis, Baill., pro parte; loc. supra cit. Claoxylon §Athroandra, Hook. f. ; Muell. arg., pro parte ; 11. supra cit. Trewia, Baill. ; loc. supra cit. Chloropatane, Engl.; Perkins \& Gilg; Wright; 11. supra cit. Rivinoides, Afzel. MSS.

Stipulae immutatae, minutae, scarioso-hyalinae. Perulae semper persistentes. Flores parvi, vix tamen minuti, semper in racemos axillares dispositi. Stamina indefinita glandulis juxtastaminalibus consociata ; glandulae extrastaminales nunquam evolutae; filamenta nisi in E. membranacea antheris manifeste breviora; antherarum locelli obovoidei. Ovarium 
semper glabrum; stigmata laevia vel in specie singula (E. africana) papillosa, nunquam laciniata lobatave; nunc sessilia, libera, elongata, linearia, patula vel recurva; nunc basi connata vel in apice styli brevis raro distincti columnaris insidentia, brevia vel brevissima, ovato-lanceolata vel suborbicularia, divaricata vel suberecta. Discus hypogynus e squamis complanatis cum carpidiis alternantibus eisque isomeris inter se liberis sed circa basin ovarii contiguis vel plane in urceolum annularem lobatum vel raro subintegrum connatis compositus.

$\S$ V. Hemierythrococca. Stigmata elongata, linearia, laevia, a basi libera. Discus hypogynus e squamis majusculis cum carpidiis alternantibus inter se liberis sed circa basin ovarii contiguis compositus. Glandulae juxtastaminales hirsutae.

T I I. Membranaceae. Calyx maris in alabastro globosus apice minute apiculatus. Filamenta antheris longiora. Stigmata praelonga, arcuatim recurva. Squamae hypogynae apice 2-lobulatae.

26. E. membranacea. Ramuli foliisque pilis patentibus molliter hispidi. Flores albi ; stamina 27.-Claoxylon membranaceum, Muell. arg. in Flora, xlvii. 437 (1864), et in DC. Prodr., xv. 778 (1866).

[IV a.] West AfriCa : Upper Guinea. Cameroons : Cameroon Mts., 4,000 ft., Mann I I 97 ! Buea, 3:300 ft., Lehmbach 212!

This species, in all other respects an Athroandra, has the long filaments characteristic of an Euerythrococca, and thus serves as a connecting link between the two sub-genera.

9 12. Patulae. Calyx maris in alabastro conico-pyramidalis. Filamenta antheris multo breviora. Stigmata elongata, patula. Squamae hypogynae apice integrae.

27. E. patula. Folia secus nervos subtus petiolisque pilis patentibus hispida, pallide viridia, basi rotundata, $20-25 \mathrm{~cm}$. longa. Stamina 50-54.Claoxylon patulum, Prain in Kew Bull. 1911, 93 (I9II).

[IVa.] WEST AFRICA: Upper Guinea. Cameroons: Jabassi, 200-250 ft., Ledermann 1063 ! I106!

A very distinct species, but at the same time, owing to the absence of female flowers, one of somewhat doubtful affinity. The hispid hairs on the leaves suggest comparison with $E$. hispida on the one hand, and with $E$. membranacea on the other. From both of these it is, however, readily distinguished specifically by the differently shaped male flower-buds and the larger number of stamens; both these species are, moreover, high-level plants. From E. membranacea it is, besides, at once distinguished by the short filaments. The similarity in shape of the male flower-buds suggests that the nearest affinity may be with the next species, but the question can only be definitely settled when the female flowers of $E$. patula are known. 
28. E. Mannii. Folia, etiam juvenilia, glaberrima, saturate viridia, basi cuneata, 8-20 cm. longa. Stamina 24-30.-Claoxylon Mannii, Hook. f. in Journ. Linn. Soc. Bot., vi. 20 (1862); Muell. arg. in DC. Prodr., xv. 2, 778 (1866).

[IV a.] West Africa : Upper Guinea. Fernando Po: Clarence Peak, 5,000 ft., Mann 260! 633 !

Mueller describes the stigmas of this species as papillose, but in Mann's original fruiting specimen they are smooth. This is the species on which Athroandra, Hook. f., was primarily based.

$\S$ VI. Chloropatane. Stigmata brevia vel brevissima, ovato-lanceolata vel suborbicularia, laevia vel in specie singula ( $E$. africana) papillosa, basi connata vel in apice styli brevis vel distincti insidentia. Discus hypogymus urceolaris, margine lobatus vel raro subinteger, vel casu e glandulis majusculis cum carpidiis alternantibus circa basin ovarii contiguis compositus. Filamenta antheris semper multo breviora.-Chloropatane, Engl. in Engl. Bot. Jahrb., xxvi. $3^{8} 3$ (1899).

I I3. 'Rivinoides.' Stylus submullus; stigmata suborbicularia, majuscula, basi connata, suberecta. Calyx maris in alabastro globosus minute apiculatus, vel breve conico-pyramidalis.-Trewia, Baill., Adansonia, i. 68, pro parte et dubitanter (1860): nec Linn. Rivinoides, Afzel. MSS.

29. E. africana. Stigmata papillosa. Calyx maris in alabastro globosus minute apiculatus. Stamina 24; glandulae juxtastaminales hirsutae. Discus hypogynus sub anthesi subinteger, fructifer 5 -lobus. Folia primum parce pubescentia, demum fere glabra.-Trewia? africana, Baill., Adansonia, i. 68 (1860). Claoxylon Barteri, Hook. f. in Journ. Linn. Soc. Bot., vi. 2 I ad calc. (1862); Stapf in Johnst. Liberia, ii. 649 (1906). C. africanum, Muell. arg. in DC. Prodr., xv. 2, 777 (1866). C. oleraceum, Prain in Kew Bull. I9II, 93 (I9II), pro parte et quoad Barter 2223 tantum.

[IV a.] West Africa: Upper Guinea. Senegambia: Casamance River, Perrottet 748 ! Sierra Leone: Crawford's Island, Afzelius! Bafodeya Hills, Scott Elliot 5505! 5647! Liberia: Sinöe Basin, Whyte! Ivory Coast: between Yaou and Ayame, Chevalier 17805 ter! Southern Nigeria: Lagos Island, Barter 2223! Western Lagos, Millen 163! Rowland! Eppah, Barter 3285 ! near Ipatu, Foster 184 ! Yoruba forests, Barter 3344 !

This species, very distinct from every other member of the genus by its stigmas, was included, in a footnote, by Hooker, within his section Athroandra. It is also the species on which the genus Rivinoides, suggested by Afzelius, was intended to be based. But while very distinct as regards its female flowers, it is only distinguishable from $E$. oleracea, so far as its male flowers are concerned, by the smaller number of stamens. The specimen of Barter 2223 at Kew, which is in leaf only, is noted as having had 40 stamens, and on this account was referred, in the Kew Bulletin, l. c., 
to $E$.oleracea. Since the description of $E$. oleracea was published, an opportunity has occurred, through the kindness of Mr. Lecomte, of examining the specimen of Barter 2223 in the Paris herbarium. This specimen admits of its flowers being examined, and shows that its male flowers have 24 stamens only, and that it identical with the type of Trewia? africana, and with Barter 3285 and Barter 3344.

30. E. Chevalieri. Stigmata laevia. Calyx maris in alabastro globosus minute apiculatus. Stamina 30 ; glandulae juxtastaminales hirsutae. Discus hypogynus 2-lobus. Folia persistenter pubescentia.--Claoxylon Chevalieri, Beille in Bull. Soc. Bot. Fr., lv. Mém. 8, 75 (1908).

[IV a.] West AfricA: Upper Guinea. French Guinea: Fouta Djalon ; Labé plateau, 3,650 ft., Chevalier I2296! Diaguissa, 4,000 ft., Chevalier I 2643 ! I 2689 !

A very distinct species, most nearly allied to $E$. a fricana, but readily recognized by its pubescent mature leaves and its smooth stigmas.

31. E. Molleri. Stigmata laevia. Calyx maris in alabastro breve conico-pyramidalis. Stamina 40; glandulae juxtastaminales glabrae. Discus hypogymus nunc completus aut late 2-lobus aut planus margine sub anthesi integer demum breviter crenulato-laciniatus; nunc e glandulis majusculis circa basin ovarii contiguis compositus. Folia glabra, juvenilia rubescentia vel purpurascentia.-Claoxylon Molleri, Pax in Bol. Broter., x. 160 (1892), et in Engl. Bot. Jahrb., xix. 84 (1894). C. purpurascens, Beille in Bull. Soc. Bot. Fr., lv. Mém. 8, 75 (I908).

[IV b.] WeSt AfriCA : Lower Guinea. St. Thomas' Island : St. Nicholas, 3,000 ft., Moller \& Quintas I 3 ! Moller I36! Henriques 22 ! 24 ! St. Thomas' Peak, 4,650 ft., Chevalier I $365^{2}$ ! I $365^{6}$ ! I $45^{27}$ ! I4582 !

A very distinct species, and the only Athroandra so far known in which the receptacular glands are glabrous. Beille has expressed the opinion that it may be an Euclaoxylon; the character of the glands favour this view, but the fact that the buds are perulate shows that it cannot be sustained. The glabrous leaves suggest a comparison with $E$. Mannii on the one hand and with $E$. rivularis on the other, but the nature of the stigmas indicates that its most natural position is near $E$. a fricana and $E$. Chevalieri. The variable nature of the hypogynous disc is unusual; the fact that sometimes the glands which alternate with the carpels are not connate in front and behind makes it serve to some extent as a link between Hemierythrococca and Chloropatane.

I I4. Rivulares. Stylus subnullus; stigmata laevia, ovato-lanceolata, basi connata, divaricata. Calyx maris in alabastro subtetragono-globosus mimute apiculatus. Glandulae juxtastaminales hirsutae.

32. E. rivularis. Stamina 40. Discus hypogynus breviter sed late 2-lobus. Folia glabra, 8-IO-nervia, I0-20 cm. longa.-Claoxylon rivulare, Muell. arg. in Flora, xlvii. 5I8 (1864), et in DC. Prodr., xv. 2, 777 (1866). Chloropatane africana, Engl. in Engl, Bot. Jahrb, xxvi. $3^{83}$ (1899); Perkins 
\& Gilg in Engl. Pflanzenr. : Monim., 24, f. 4 M-R (I 90I) ; Wright in Thiselton-Dyer, Flor. Trop. Afr., vi. I, I69 (I909).

[IV b.] WeSt Africa: Lower Guinea. Cameroons: Kribi; Great Batanga, Dinklage 1057! Yaunde; Zenker 494, 798 (ex Engler). Spanish Guinea : Mont John River; Kongui, Mann I785!

A very distinct species, which forms the basis of the proposed genus Chloropatane. We have not seen specimens collected by Zenker at Yaunde, bearing the numbers cited.

I I 5. Columnares. Stylus columnaris; stigmata laevia, suborbicularia, minima, stylo multo breviora, suberecta. Calyx maris in alabastro globosus minute apiculatus, vel breve conico-pyramidalis. Glandulae juxtastaminales hirsutae. Discus hypogynus mimute 2-lobus.

33. E. Welwitschiana. Bracteolae ovatae, I mm. longae. Calyx maris in alabastro globosus, minute apiculatus. Stamina 30. Folia 10I $5 \mathrm{~cm}$. longa, demum fere glabra.-Claoxylon Welwitschianum, Muell. arg. in Journ. Bot., ii. 333 (1864), et in DC. Prodr., xv. 2, 776 (1866); Hiern in Cat. Afr. Pl. Welw., 975 (1900). C. africanum, De Wild. in Ann. Mus. Congo, Bot., sér. 5, ii. 279, in parte et quoad spp. Sapiniana apud Sankuru lecta tantum (I 908); Dur., Syll. Flor. Cong., 49I , in parte et quoad spp. Sapiniana (1909); De Wild., Comp. Kasai Miss. Scient., 330 (1910): nec Muell. arg. Chloropatane Batesii, Wright in Thiselton-Dyer, Flor. Trop. Afr., vi. I, I69 (1909), et in Kew Bull. 1909, 214 (1909).

[IV b.] West AFriCA : Lower Guinea. Cameroons : Kribi ; Bipindi, 500-600 ft., Zenker I908! 2049! 2610! 2910! 2925!3773!3912! Ebolowa ; Efulen, Bates 409! Spanish Guinea: Nkolentangan, Tessmann 296! Gaboon: without precise locality, Klaine 2976! Portuguese West Africa: Angola; Golungo Alto, on the Zuenza River, Welwitsch 397 ! Gossweiler 44I 2 ! Serra da Alta Queta, Welwitsch 398 !

V. West Central Africa. Congo State: Kasai ; Sankuru, Sapin!

A very distinct species. Sapin states that the leaves of this plant are edible and form an excellent vegetable.

34. E. columnaris. Bracteolae ovatae, I $\mathrm{mm}$. longae. Calyx maris in alabastro conico-pyramidalis. Stamina $48-54$. Folia $4-7 \mathrm{~cm}$. longa, adpresse pubescentia.-Claoxylon columnare, Muell. arg. in Flora, xlvii. 437 (1864), et in DC. Prodr., xv. 2, 776 (1866). II 39 !

[IV. b.] West AfRICA: Lower Guinea. Prince's Island: Mann

Very nearly allied to $E$. Welzwitschiana and indistinguishable as regards female flowers; the male flowers differ considerably in shape and in having more numerous stamens. The two are, however, readily distinguished by their different leaves. 
35. E. Poggei. Bracteolae subulatae, $2 \mathrm{~mm}$. longae. Calyx maris in alabastro conico-pyramidalis. Stamina 60 . Folia $4-7 \mathrm{~cm}$. longa, patule pubescentia.-Claoxylon columnare, Engl. in Sitzb. Preuss. Akad. Wiss., xxxviii. 829 (1908); Dur., Syll. Flor. Cong., 656 (1909): nec Muell. arg. C. Poggei, Prain in Kew Bull. 1911, 93 (I9II).

[IV.b] WeST AFRICA: Lower Guinea. Congo State: neighbourhood of Lazaret, Vanderyst!

[V.] West Central Africa. Congo State: Kasai ; Mukenge, Pogge 1373 ! Kwango ; without precise locality, Butaye!

The affinity of this species is somewhat doubtful, though the probability is that it may be most nearly allied to $E$. columnaris. The female plant is not yet known; should it prove to have a columnar style with minute stigmas it may be possible to adopt Engler's view and refer the plant to $E$. columnaris; even then, however, it will be necessary to treat it as a distinct variety, readily recognized by its somewhat hispidulous, spreading hairs, and its longer bracteoles.

9f 16. Oleraceae. Stylus brevis; stigmata laevia, ovato-lanceolata, sub anthesi divaricata dein recurva, stylo longiora. Calyx maris in alabastro globosus minute apiculatus. Glandulae juxtastaminales hirsutae.

36. E. atrovirens. Folia adpresse pubescentia, basi cuneata vel rotundata, 8-10 cm. longa. Stamina 30-40. Discus hypogymus eccentros, integer. Cocci $6 \mathrm{~mm}$. lati.-Claoxylon atrovirens, Pax in Engl. Bot. Jahrb., xix. 85 (1894); Dur. \& Schinz in Étud. Flor. Cong., 245 (I896); Dur., Syll. Flor. Cong., 49I (I 909). Claoxylon sp., Dawe, Bot. Miss. Ugand., 56 ( I 906). C. inaequilaterum, Pax in Engl. Bot. Jahrb., xliii. 320 (I 909).

[IVa.] West Africa: Upper Guinea. Cameroons: Tchâpe Pass, 4,800 ft., Ledermann 2653! Babangi Tungo ; Bamessing, 4,500 ft., Ledermann $5^{823}$ !

[V.] West Central Africa. Congo State: Arumwimi; Yambuya, Solheid 32 ! Uelle; Bomokandi, at Kussumbo in the Monbuttu country, Schweinfurth 3 186!

[IX.] East Central Africa. Congo State: Eastern Province; Kwa Muera, at Fort Beni on the Semliki, Mildbraed 2246! 240I! Muera, 3,300-3,600 ft., Mildbraed 227I! 2277! Uganda: Western Province; Unyoro, at Hoima, 3,500 ft., Bagshawe I5I2! Uganda Province; Chagwe, 3,900 ft., Dawe 2I 5 ! Entebbe, 3,900 ft., Brown 356! German East Africa : Bukoba ; Stuhlmann 3923!

It has not been found possible to keep Claoxylon inaequilaterum apart from $E$. atrovirens; the flowers of the two are the same in both sexes. In some of the specimens of $C$. inaequilaterum the leaves agree in shape with those of some of the specimens of $E$. oleracea, but as regards indumentum they agree with those of 
$E$. atrovirens, and the extreme forms, with cuneate and rounded bases respectively, are connected by intermediates.

37. E. oleracea. Folia secus nervos puberula mox glabrescentia, basi rotundata, 6-I5 cm. longa. Stamina 30-40. Discus hypogynus eccentros, integer. Cocci $6 \mathrm{~mm}$. lati.-Claoxylon africanum, De Wild. \& Dur. in Bull. Herb. Boiss., sér. 2, i. 47 (Igco), et in Ann. Mus. Congo, Bot., sér. 3, ii. 209 (190 I) ; De Wild. in Miss. Laurent, i. I30 (I905) ; Rendle in Journ. Linn. Soc. Bot., xxxvii. 2 I 3 (I905); De Wild. in Ann. Mus. Congo, Bot., sér. 5, ii. 279, spp. Sapiniana tamen excludenda (I 908) ; Dur., Syll. Flor. Cong., 49 I, spp. Sapiniana excludenda (I909) : nec Muell. arg. C. oleraceum, Prain in Kew Bull. I9I I, 94, syn. Hook. et Muell. arg. excludenda (19I I).

[IV a.] West Africa: Upper Guinea. Cameroons : Tchâpe Pass, 5,000 ft., Ledermann 2845! Tibati, 3,000 ft., Ledermann 2423!

[IV b.] Lower Guinea. Cameroons: Yaunde, 2,700 ft., Zenker \& Staudt 2II! Zenker I84! 499! 7I2! Spanish Guinea: Bebao, Tessmann 555 ! Congo State (Lower Congo) : Stanley Pool. Dist. ; Kisantu, Gillet 37 ! 74! I419! I865! Kimuenza, Gillet 2144! Lukolela, Dewevre 748 !

[V.] West Central Africa. Congo State: Lake Leopold II Dist.; near Lake Leopold II, Body 92 ! Equatorial Dist.; Eala, Pynaert 525 ! 920! Lulonga, Pynaert 767 ! Injolo, Huyghe \& Ledoux 22! Bangala Dist.; Bumba, Laurent! Abumonbasi, Thonner 200 ! Uelle Dist. ; Paku, Seret!

[IX.] EAst Central Africa. Uganda: Uganda Province; coast of Lake Victoria Nyanza, 4,000 ft., Bagshawe .588!

Very nearly allied to $E$. atrovirens and not distinguishable by floral characters, in either sex, from that well-marked species. As a rule, however, the two are quite unlike each other as regards shape of leaf, while they possess a different indumentum. So distinctive a facies is thus imparted to the two plants that hitherto no confusion has taken place between them. On the other hand, the general facies of $E$. oleracea is so like that of $E$. Welwitschiana that it bears as close a resemblance to $E$. africana as $E$. Weluritschiana does. Male specimens of these three species, on this account, call for care in their discrimination, and the writer has experienced exactly the difficulty which others have met with. Fortunately, however, the female flowers of these three plants are widely different, the stigmas of $E$. africana being subsessile and papillose, those of the other two smooth and at the apex of a distinct style. But these two are readily distinguishable because the stigmas of $E$. Welwitschiana are very small and suberect, much shorter than the style, while those of $E$. oleracea are at first divaricate and ultimately recurved and longer than the style. It is to be remarked that in the extreme west ( $\mathrm{N}$. Cameroons) of the wide area which the two allies occupy and again in the extreme east (Uganda proper) of this area, $E$. atrovirens and $E$. oleracea occur together. In the intervening region, however, $E$. atrovirens has so far only been found to the north of the Congo, while 
$E$. oleracea appears to take its place to the south of that river, though it also occurs north of the Congo in Bangala and Uelle.

In Lake Leopold II district, according to Body, the leaves are used as a vegetable; according to Huyghe and Ledoux, both the leaves and the flowers are similarly employed in the Equatorial district.

38. E. angolensis. Folia adpresse pubescentia, basi late cuneata, 5-8 cm. longa. Stamina ignota. Racemi feminei 4-flori. Discus hypogynus zygomorphos, utrinque breviter 2-lobus. Cocci $6 \mathrm{~mm}$. lati.-Claoxylon angolense, Muell. arg. in Journ. Bot., ii. 333 (1864), et in DC. Prodr., xv. 2, 777 (1866); Hiern in Cat. Afr. Pl. Welw., 975 (1900).

[IVb.] West Africa: Lower Guinea. Portuguese West Africa : Angola ; Loanda, Pungo Andonga near Luxillo, Welwitsch 399!

A very distinct species.

39. E. flaccida. Folia adpresse pubescentia, basi late cuneata, $5-8 \mathrm{~cm}$. longa. Stamina 34. Racemi feminei 12-16-flori. Discus hypogymus zygomorphos, utrinque altius 2-lobus. Cocci $6 \mathrm{~mm}$. lati.-Claoxylon flaccidum, Pax in Engl. Bot. Jahrb., xix. 86 (1894) ; Dur. \& Schinz in Étud. Flor. Cong., 245 (1896); Dur., Syll. Flor. Cong., 49 I (1909). C. Schweinfurthii, Pax in Engl. Bot. Jahrb., xix. 86 (I 894); Dur. \& Schinz in Étud. Flor. Cong., 245 (I896).

[V.] West Central Africa. Niam-Niamland: Nabambisso, Schweinfurth 3056! Congo State: Uelle; Bomokandi, in the Monbuttu country, at Munsa's dorf, Schweinfurth $335^{\mathrm{I}}$ in Herb. Berlin! Munsa, Schweinfurth 3355 in Herb. Kew !

Very nearly allied to $E$. angolense, and perhaps only a form of that species, from which it differs in having rather longer petioles, female racemes with more numerous flowers, and a more prominently 2 -lobed hypogynous disc. No good character is available whereby to distinguish the Niam-Niam plant (Claoxylon Schweinfurthii, Pax) from the Monbuttu one (C. flaccidum, Pax).

40. E. macrophylla. Folia adpresse pubescentia, basi angustiore cuneata, 22-25 cm. longa. Stamina 24. Discus hypogymus ignotus. Cocci ignoti.-Claoxylon macrophyllum, Prain in Kew Bull. I9I I, 95 (I9I I).

[IX.] East Central Africa. Congo State: Eastern Province; Fort Beni, Kwa Muera, Mildbraed 2197!

A very distinct species, the precise affinity of which cannot be determined in the absence of female flowers and fruits. It is perhaps most nearly allied to $E$. Dewevrei and $E$. hispida, but it is readily distinguished from both by the shape of its leaves and the absence of hispid hairs.

41. E. hispida. Folia secus nervos pilis patentibus hispida, subtus inter nervos glabra minute verrucosa, basi rotundata vel late cuneata, 12-20 cm. longa. Stamina 27. Discus hypogymus zygomorphos, utrinque 
late 2-lobus. Cocci $9 \mathrm{~mm}$. lati.-Claoxylon hispidum, Pax in Engl. Bot. Jahrb., xix. 85 (1894).

[IVa.] West AfRICA : Upper Guinea. Cameroons: Buea, 5,3co ft., Preuss 888! 908! Deistel! Lehmbach 179 ! Reder 638! Great Cameroon, 5,3co ft., Mildbraed 3459 !

A very distinct species, readily distinguished from all the others except E. Dewevrei by its relatively large fruit.

42. E. Dewevrei. Folia secus nervos pilis patentibus hispida, subtus inter nervos densius tomentosa, basi rotundata, IO-12 cm. longa. Stamina 24. Discus hypogynus zygomorphos, utrinque late 2-lobus. Cocci $9 \mathrm{~mm}$. lati.-Claoxylon Dervevrei, Pax in De Wild. \& Dur., Ann. Mus. Congo, Bot., sér. 3, ii. 209 (I90I), et in Engl. Bot. Jahrb., xxxii. 283 ( I903); Dur., Syll. Flor. Cong., 49I (I909).

[IV a.] West Africa : Upper Guinea. Cameroons : Babadji, 5,200 ft., Ledermann 5988 !

[V.] West Central Africa. Congo State: Eastern Province; Maniema, Nyangwe, Deweore 947 !

Very nearly allied to $E$. hispida, from which it differs in having the leaves rather densely tomentose beneath between the hispid nerves. The plant from Babadji, Cameroons, with male flowers, agrees well in this respect with Dewevre 947 from Nyangwe, Congo State, which is female. With Dewevre 947 in the original citation is associated another specimen, Dewevre 964 a, also from Nyangwe. This latter plant agrees as regards pubescence with $E$. hispida and not with $E$. Dervevrei, but it differs so markedly from both in the size and form of its leaves that it may be necessary, where fuller material is available, to treat it as a distinct species. Besides differing as regards foliage, it has a larger number of stamens than $E$. hispida has, or than the Cameroon plant which agrees as regards foliage with the female plant on which $E$. Derwerrei was based. In the meantime, it may be left in $E$. Dewerrei, where De Wildeman and Durand have placed it, but must be treated as a distinct variety, characterized as follows :-

E. Dewevrei, var. inopinata. Folia secus nervos pilis patentibus hispida, subtus inter nervos glabra minute verrucosa, basi cuneata, $5 \mathrm{~cm}$. longa. Stamina 40. Discus ignotus. Cocci ignoti.-Claoxylon Deweevrei, De Wild. \& Dur. in Ann. Mus. Congo, Bot., sér. 3, ii. 209, partim (I90I); Dur., Syll. Flor. Cong., 49 I, partim et quoad Dewevre 964 a tantum (1909) : vix Pax. An species distincta?

[V.] West Central Africa. Congo State: Eastern Province; Maniema, Nyangwe, Dewevre 964 a!

According to Dewevre the leaves of this variety are edible.

An examination of this conspectus shows that in a certain number of instances species may be barely distinguishable as regards foliage, and may even closely resemble each other as regards male flowers, but may 
nevertheless be readily separable by their female flowers. This is particularly true of E. subspicata and E. Poggeophyton, which agree closely in other respects, yet differ so much as regards the female flowers that the latter species has been looked on as the type of a distinct genus. Another case in which this difficulty is marked is as regards $E$. Welwitschiona and $E$. olevacea, which can hardly be distinguished by their foliage, and again as regards E.oleracea and E. africana, which have been somewhat consistently mistaken for each other. Yet in the case of these three species the female flowers differ so greatly that each belongs to a distinct natural group.

But the conspectus reveals a converse fact. In a considerable number of cases the forms which it is necessary, for the moment, to recognize, are associated in pairs which practically agree as regards their flowers, and are only to be distinguished by differences in tomentum, in shape of leaf, or in the number of flowers in their respective inflorescences. Doubts therefore arise as to whether the differences in question do not indicate varieties rather than species; it is conceivable that in some cases further material may justify the union of these pairs. Aggregation has, however, been carried as far as the available material will justify; all that can be done is to provide, for the use of workers in the field, a brief synopsis of the situation, in the hope that the material which is required to confirm or dispel these doubts may be obtained.

In Adenoclaoxylon, E. mitis, Pax, may be only an inland form of the littoral E. Kirkii (Claoxylon Kirkii, Muell. arg.) ; E. rigidifolia, Pax, may be merely a state of E. bongensis, Pax ; E. Paxii, Rendle, may be no more than a variety of $E$. Fischeri, Pax. In Deflersia, E. berberidea, Prain, may be only a very distinct variety of $E$. natalensis, Prain ; E. subspicata, Prain, may prove to be the normal condition of a species whereof Poggeophyton aculeatum, $\mathrm{Pax}$, is a teratological condition. In Trichogyne, E. Menyharthii (Claoxylon Menyharthii, Pax) may be the usual state of a species whereof E. tristis (Claoxylon triste, Muell. arg.) is a local and uncommon condition; $E$. hirta, Pax, may be only a variety of E. trichogyne (Claoxylon trichogyne, Muell. arg.). Finally, in Chloropatane, E. Poggei, Prain, may, as Engler has already stated, be referable to $E$. columnaris (Claoxylon columnare, Muell. arg.) ; E. oleracea, Prain, may prove to be only a distinct variety of E. atrovirens (Claoxylon atrovirens, Pax); E. flaccida (Claoxylon flaccidum, $\mathrm{Pax}$ ) is almost certainly only a form of E. angolensis (Claoxylon angolense, Muell. arg.); E. Dewevrei (Claoxylon Dewevrei, Pax) is perhaps only the normal condition of a species whereof E. hispida (Claoxylon hispidum, Pax) is a striking local form.

However, even if, in each of these cases, the suggested reduction should ultimately prove to be necessary, the genus Erythrococca, as here recognized and limited, will still include over thirty well-characterized species. 


\section{MicRococcA, Benth. ampl.}

Micrococca, Benth. in Hook., Niger. Fl., 5ॅ०3 (1849); Baill., Etud. gén. Euphorb., $43^{6}$ ( $185^{8}$ ), pro parte ; Benth. in Benth. et Hook.f. Gen. Plant., iii. $3 \circ 9$ (I880); Pax in Engl. \& Prantl, Nat. Pflanzenf., iii. 5, 48 (1890).

Mercurialis, Pluk., Phytogr., t. 205, f. 4 (1692), et Almag., 248 (I696) ; Lamk., Encyc. Meth., iv. I20 (1796); Baill., Étud. gén. Euphorb., 490 (I 858), in Adansonia, i. 76 (1860), iii. I75 (1862), et in Hist. des Plantes, v. 210 (1874), pro parte: nec Linn.

Tragia, Linn. Sp. Pl., 980 (I753); Willd., Sp. Pl. iv. 324 (I805); Roxb., Flor. Ind., iii. 576 (I832); Grah., Cat. Bomb. Pl., I 86 (I839), pro parte.

Microstachys, Dalz. \& Gibs., Bomb. Flor., 227 (I86I) : nec A. Juss.

Claoxylon, Thw., Enum. Pl. Zeyl., 271 (1861) ; Muell. arg. in Linnaea, xxxiv. I66 (I865), et in DC. Prodr., xv. 2, 789 (I866), pro parte: Hook. f., Flor. Brit. Ind., v. 4I 2 (I887), pro parte; Trimen, Handb. Flor. Ceyl., iv. 63 (1898) ; Hiern, Cat. Afr. Pl. Welw., 976 (19co), pro parte ; Prain, Beng. Pl., 947 (1903); Cooke, Flor. Pres. Bomb., ii. 609 (I906) : nec A. Juss.

Flores dioici vel monoici, apetali. or Calyx membranaceus in alabastro globosus apice minute apiculatus, primum clausus, sub anthesi valvatim 3-partitus. Stamina definita vel indefinita $(3-30)$, in receptaculo plus minusve elevato centralia, saepe pluriseriata, nunc glandulis rhombeis inter se liberis et apice pilis viscidulis onustis consociata, nunc receptaculo nudo inserta; filamenta antheras aequantia vel iis breviora ; antherae 2-loculares; loculi obovoidei vel sublineares, basifixi, erecti, praeter basin inter se liberi, extrorsim rimosi. Rudimentum ovarii nullum. \& Calyx 3-4-partitus, lobis quam in mare majoribus, imbricatis. Ovarium plus minusve pubescens vel substrigosum, 3-loculare vel raro 4-loculare, profunde sulcatum; loculi laciniis calycis oppositi vel is pauciores; ovula in quoque loculo solitaria ; stigmata loculis ovarii isomera, elongata, linearia, patula, a basi libera totaque plumoso-laciniata. Discus hypogynus e squamis linearibus complanatisve cum carpidiis alternantibus eisque isomeris compositus. Fructus capsularis ; capsula 3-cocca, raro 4-cocca, interdum abortu 2-cocca, didyma; cocci subglobosi, tenuiter crustacei, extra parce pubescentes vel subglabri, fere a basi distincti, loculicide septicideque simul dehiscentes et 2-valvatim dissilientes. Semina fere sphaerica, arillo pertenui involuta; testa crustacea, foveolato-reticulata ; albumen carnosum ; embryo axilis ; radicula conica vel subcylindrica; cotyledones subangusti vel lati, complanati, oblongi vel suborbiculares.-Frutices vel herbae, inermes; gemmae haud perulatae. Folia alterna, petiolata, saepe primum purpurascentia, membranacea, margine plus minusve dentata; stipulae minutae. Flores minuti, secus rhachides racemorum axillarium in glomerulos vel in spiculas bracteolis imbricatis 
obtectas dispositi ; glomeruli vel spiculae inter se distantes. Racemi fasciculati vel solitarii, saepius unisexuales, nonnunquam androgyni; pedunculi rhachidibusque gracillimi; bracteae parvae; pedicelli articulati, masculi breves, feminei longiores; bracteolae minutae. Racemi I-sexuales nunc masculi glomerulis plurifloris, nunc feminei glomerulis $\mathbf{I}-2$-floris; racemi androgyni nunc glomerulis masculis plurifloris cum singulo femineo terminali, nunc glomerulis paucifloris floribus masculis brevissime pedicellatis I-2 cum unico centrali femineo longius pedicellato in quoque fasciculo.

\section{Clavis SPECIERUM.}

Racemi I-sexuales; frutices perennantes:-

Receptaculum maris glandulis interstaminalibus

instructum; folia longe petiolata :-

Racemi foliis longiores, spiculigeri

I. M. oligandra.

Racemi foliis breviores, glomeruligeri :-

Folia parce pubescentia

Folia dense hirsuta

2. M. Wightii.

2 b. M. Wightii, var. hirsuta.

Receptaculum maris eglandulosum :-

Folia basin versus longe gradatim attenuata, brevissime petiolata

Folia longe petiolata :-

Racemi masculi glomeruligeri

Racemi masculi spiculigeri :-

Folia basi acuta

Folia basi late cuneata vel obtusa

Racemi androgyni ; folia longe petiolata :-

Frutex perennans; flos terminalis in quoque racemo femineus; receptaculum maris eglandulosum

3. M. Humblotiana.

4. M. capensis.

5. M. Beddomei. 6. M. Holstii.

Herba annua; flos centralis in quoque glomerulo femineus; receptaculum maris glandulis interstaminalibus instructum

8. M. Mercurialis.

1. M. oligandra. Racemi I-sexuales foliis longiores. Flores masculi ad apices spicularum remotarum bracteolis dense imbricatis obtectarum dispositi; stamina glandulis interstaminalibus consociata. Frutex perennans; folia ovato-lanceolata, longe petiolata, basi cuneata vel raro obtusa.-Claoxylon longifolium, Baill., Étud. gén. Euphorb., 493 (I 858) in parte, syn. Erythrochilus longifolius, B1. exclud.; Thw., Enum. Pl. Zeyl,, 27 I (1859). C. oligandrum, Muell. arg. in Linnaea, xxxiv. I64 (1865), et in DC. Prodr., xv. 2, 784 (I866) ; Hook. f., Flor. Brit. Ind., v. 412 (1887); Trimen, Handb. Flor. Ceyl., iv. 64 (I898).

AsIA : Ceylon. Moist regions in forests at from 2,000 to $5,000 \mathrm{ft}$. ; Matale; Deltota ; Maskeliya ; Maturata ; Gardner 6! 165! 780! Walker 37 ! Thwaites 2102! 2499! Wight 2641! 
2. M. Wightii. Racemi I-sexuales foliis breviores. Flores masculi in glomerulos inter se remotos aggregati ; stamina glandulis interstaminalibus consociata. Frutex perennans; folia oblongo-lanceolata, parce hispida, longe petiolata, basi cuneata.-Claoxylon Wightii, Hook. f., Flor. Brit. Ind., v. 413 (I887).

AsiA : India. Malabaria : Travancore ; Courtallam, Wight 2676 ! Tinivelli Hills, Beddome!

var. hirsuta. Folia dense hispida.-Claoxylon hirsutum, Hook. f., Flor. Brit. Ind., v. 4I3 (I887).

ASIA : India. Malabaria: Travancore; Tinivelli Hills, Beddome!

3. M. Humblotiana. Racemi I-sexuales foliis breviores. Flores masculi in glomerulos inter se remotos aggregati vel interdum inferiores in racemulos perbreves inter se remotos dispositi ; receptaculum maris eglandulosum. Frutex perennans; folia oblanceolata basi sensim in petiolum abbreviatum attenuata.-Claoxylon Humblotianum, Baill., Bull. Soc. Linn. Par., 996 (1892).

Mascarene Islands: Comoros. Johanna; 2,000 ft., Humblot 222 ! Kirk!

4. IM. capensis. Racemi I-sexuales foliis breviores vel aequilongi, vel masculi interdum foliis longiores. Flores masculi in glomerulos inter se remotos aggregati; receptaculum maris eglandulosum. Frutex perennans; folia elliptico-lanceolata, longe petiolata, basi cuneata.-Claoxylon capense, Baill., Étud. gén. Euphorb., 493 (I 858 ), et in Adansonia, iii. I6I (I862); Muell. arg. in DC. Prodr., xv. 2, 786 (1866) ; Sim in Flor. Port. E. Afr., I05 (1909).

Africa : South-East Africa. Mozambique: Lourenço Marques, Sim. Zululand: Entumeni, Wood 3979! Ngoya, I,000-2,000 ft., Wylie (Herb. Wood 7905)! Wood II570! Natal: without precise locality, Gerrard I I79! Pondoland: near the Umsikaba River, Drège $463^{6}$ ! without precise locality, Bachmann 805 !

5. M. Beddomei. Racemi I-sexuales foliis aequilongi vel breviores. Flores masculi ad apices spicularum remotarum bracteolis dense imbricatis obtectarum dispositi; receptaculum maris eglandulosum. Frutex perennans; folia elliptico-lanceolata, longe petiolata, basi acuta.-Claoxylon Beddomei, Hook. f., Flor. Brit. Ind., v. 4I3 (I887).

AsIA : India. Malabaria: Travancore ; Anamalai Hills, Beddome!

6. II. Holstii. Racemi I-sexuales foliis aequilongi. Flores masculi ad apices spicularum remotarum bracteolis dense imbricatis obtectarum dispositi; receptaculum maris eglandulosum. Frutex perennans; folia ovata vel elliptica, longe petiolata, basi late cuneata.-Claoxylon Holstii, Pax in Engl. Bot. Jahrb., xxxiv. 372 (1904). 
AFRICA : East Africa. German East Africa: East Usambara; near Amani, 2,800 ft., Engler 6I I ! near Gonja, Holst 426I!

7. M. Volkensii. Racemi androgyni flore terminali femineo, foliis breviores. Flores masculi superne in glomerulos aggregati, basin versus ad apices spicularum bracteolis laxe imbricatis obtectarum dispositi ; receptaculum maris eglandulosum. Frutex perennans; folia lanceolata, longe petiolata, basi acuta.-Claoxylon Volkensii, Pax in Engl. Pflanzenw. OstAfrik., C, 238 (1895), et in Engl. Bot. Jahrb., xxiii. 524 (1897).

AfriCA : East Africa. German East Africa: Kilimanjaro; Marangu, 7,000-7,500 ft., Volkens 1001! Engler I766! Uhlig 131!

8. M. Mercurialis, Benth. in Hook., Niger Fl., $5 \circ 3$ (1849). Racemi saepissime androgyni foliis aequilongi vel is longiores. Flores masculi nunc pauci cum unico centrali femineo consociati nunc plures absque femineo in glomerulos inter se remotos aggregati; stamina glandulis interstaminalibus consociata. Herba agrestis annua; folia ovata, longe petiolata, basi cuneata vel obtusa.-Baill., Étud. gén. Euphorb., 436 (1858); Pax in Engl. Pflanzenw. Ost-Afrik., C, 238 (I895) ; Dur. \& De Wild., Bull. Soc. Bot. Belg., xxxvii. 105 (1898); Schweinf., Bull. Herb. Boiss., vii. App. 2, 306 (1899); De Wild. \& Dur., Ann. Mus. Congo, Bot., sér. 2, i. 50 (1899); sér. 2, ii. 57 (1900) ; sér. 3, ii. 209 (I90I) ; De Wild., Miss. Laurent, i. I 29 (I905), et in Ann. Mus. Congo, Bot., sér. 5, ii. 279 (I908) ; Dur., Syll. Flor. Cong., 492 (I909). Mercurialis maderaspatensis tricoccos acetabulis destituta, Pluk., Phytogr., t. 205, fig. 4 (1692), et in Almagest., 248 (1696). Mercurialis alternifolia, Lamk., Encyc. Meth., iv. I20 (I 796); Baill., Étud. gén. Euphorb., 490 (1858), et in Adansonia, i. 76 (1860); iii. I75 (1862). Tragia foliis ovatis, Linn., Flor. Zeyl., 334 (I747). T. Mercurialis, Linn., Sp. Pl., 980 (I753); Willd., Sp. Pl., iv. 324 (1805) ; Roxb., Flor. Ind., iii. 576 (I832); Grah., Cat. P1. Bomb., I86 (1839); syn. Rheede excl. Microstachys Mercurialis, Dalz. \& Gibs., Bomb. Flor., 227 (1861). Claoxylon Mercurialis, Thw., Enum. Pl. Zeyl., 27I (I86I) ; Hook. f., Flor. Brit. Ind., v. 4I 2 (I 887); Trimen, Handb. Flor. Ceyl., iv. 63 (1898) ; Woodr., Journ. Bomb. Nat. Hist. Soc., xii. 372 (I899) ; Hiern, Cat. Afr. Pl. Welw., 976 (1900) ; Prain, Beng. Pl., 947 (I903); Cooke, Flor. Bomb. Pres., ii. 609 (I906).

AfrICA : West Africa (Upper Guinea). Senegal: without precise locality, Perrottet 7I5! Sierra Leone: near Regent, Scott Elliot 4II7! without precise locality, Afzelius 419! Liberia: Grand Bassa, at Fishtown and Monrovia, Dinklage 1659! Togo: Lome, Warnecke 187! Misahohe, Baumann 258! Bismarckburg, Buettner 32I! Southern Nigeria: Lower Niger, Vogel 194! Nupe, Barter 1494! Cameroons: Kriegsschiffhafen, Schlechter I2394!

West Africa (Lower Guinea). Cameroons : Batanga, Dinklage 647! 648 ! Bates I22! Spanish Guinea: Nkolentangan, Tessmann 416 ! Congo 
State (Lower Congo): Boma ; Zambi, Dupuis. Mayumbe; Bingila, Dupuis. Matadi ; near Matadi, Laurent. Stanley Pool Dist.; Kisantu, Gillet; near Dembo, Gillet; Vanderyst; near Yumbi, Laurent $42 \mathrm{I}$; near Kwamouth, Bieler. Angola: Golungo Alto; near Sobati, Welwitsch 394! Pungo Andongo; near Pedra Cabondo, Welwitsch 395 !

West Central Africa. Congo State: Kwango; Eiolo, Laurent. Lake Leopold II Dist.; Kutu, Laurent; Kiri, Laurent. Aruwimi Dist.; near Bena-kamba, Dewevre I 89; Limbutu, Laurent. Uelle; Niam-Niamland, at Mbomu, Schweinfurth 3997 ! Paku, Seret. Lualaba-Kasai Dist.; Mukenge, Pogge I 332 !

East Africa (Mozambique). Nyasaland: Lower Shire; Elephants' Marsh, Scott!

East Africa (Zanzibaria). German East Africa : Usaramo, Stuhlmann 6380! Madossi, Stuhlmann 8119! Dar-es-Salam, Stuhlmann 8526! Island of Zanzibar: Hildebrandt $\mathrm{IO}_{3} 8$ !

East Central Africa. Uganda : Entebbe, $3900 \mathrm{ft}$., Brozen 25!

North-East Africa. Abyssinia : without precise locality, Schimper! Ehrenberg. Eritrea: Saati, $470 \mathrm{ft}$., Schweinfurth 22! Schweinfurth \& Riva 487! Nubia: Samhar, near Massowah, Hildebrandt 736 !

MaSCAREne Islands : Madagascar. Nossibé ; Boivin!

ASIA : Arabia. Yemen: Agara near Hodjela, I,750 ft., Schweinfurth 1973. Wadi Hille; near Wolledje, at the foot of Gebel Melhan, 2,000 ft., Schweinfurth 777 .

India. Bombay: Porbundar; Woodrow. North Canara; Carwar, Talbot! Northern India: Behar; Monghir, Wallich! Southern India: Mysore; Law! base of Anamalai Hills, Beddome! Nilgiri Hills ; Sigur, 3,000 ft., Gamble! Coromandel; near Madras, Koenig! Wight! Shuter! G. Thomson!

Ceylon. Throughout the low country, Walker! Thwaites 3310 !

Indo-China. Burma: Pegu; Petroleum Wells on the Irrawadi, Wallich! Malaya. Malay Peninsula: Pulo Uban; Granite quarries, Ridley 374 !

\section{Distribution OF ERYTHROCOCCA AND MicrococCA.}

In discussing the distribution of the African species of any genus we have at our disposal two somewhat different systems of subdivision of the continent ; that adopted in the 'Flora of Tropical Africa', and that employed in 'Die Pflanzenwelt Afrikas'. Each of these systems serves very well the purpose it is intended to fulfil. Neither system, however, is wholly suitable to a sketch like the present; the former because of the respect it is compelled to pay to the accidental situation of existing political frontiers ; the latter because of the detail to which the subdivision of the natural regions 
recognizable on physiographical grounds is necessarily carried. These natural regions, ten in number, but in three instances conveniently subdivisible, are here treated as primary ; to facilitate the use of a map, existing political areas are also indicated. To avoid confusion, the limits of these natural regions may be briefly stated:-

I. NORTH AFrICA. Mediterranean sea-board to the northern edge of the Sahara: Atlantic sea-board, between Tangier and Cape Nun, to the eastern fringe of the Libyan Waste.

\section{The Sahara.}

III. North Central Africa. Southern edge of the Sahara to the northern boundary of Upper Guinea and the Congo-Chad divide; Atlantic sea-board, between Lake Taniahya and the Gambia, eastward to Dar Fertit and the Nile-Chad divide. This region includes the catchment areas of the Senegal to its mouth, of the Niger and the Benue to their confluence, and of the streams that empty into Lake Chad.

IV. West AfricA. Belt roughly 200 miles wide inland from the Atlantic sea-board, the River Gambia on the north and Benguella on the south. This region includes the Lower Niger basin from Lokoja to the sea and the Lower Congo Basin below Stanley Pool ; it admits of convenient subdivision into:-

(a) Upper Guinea. River Gambia to the River Sanaga; with Fernando Po.

(b) Lower Guinea. River Sanaga to Benguella; with Prince's Island and San Thomé.

V. West Central Africa. Catchment area of the Congo as far as Stanley Pool.

VI. South-West Africa. Congo-Kunene and Congo-Zambesi divides southward to the Roggeveld, Nieuweveld, and Zuurberg ranges : Atlantic sea-board, between Benguella and Olifant's River, eastward to Lake Nyasa, and the Kirk, Melsetter, Lebombo, and Drakensberg ranges. This region includes the catchment areas of the Cunene and the Orange-Vaal to their mouths, of the Zambesi to Tete, and of the Limpopo and other streams to the Mozambique frontier.

VII. South-East Africa. Coast and Central zones of Cape Colony and Natal, between the Roggeveld, Nieuweveld, Zuurberg, and Drakensberg ranges and the sea, from Olifant's River to Delagoa Bay. This region admits of convenient subdivision into :-

(a) Cape. Olifant's River to the Kei.

(b) Natal. Kei River to Delagoa Bay.

VIII. EAST AFrica. Belt of varying width from the Indian Ocean 
sea-board between Delagoa Bay and the River Juba, inland to the Lebombo, Melsetter, and Kirk ranges, Lake Nyasa, a line from the northern end of Nyasa to the eastern base of Kilimanjaro, thence to the eastern base of Kenia, thence to Lake Rudolf: limited on the north by a line joining the northern ends of Lakes Rudolf and Stefanie and projected eastward to the River Dawoe, thereafter by the Dawoe-Juba. This region admits of convenient subdivision into:-

(a) Mozambique. Delagoa Bay to the Rovuma.

(b) Zanzibaria. Rovuma River to the Juba; with Mafia, Zanzibar, and Pemba.

IX. East Central Africa. Limited on south and west by a line from the northern end of Nyasa to Tanganyika, by Lake Tanganyika, the Congo-Nile and the Nile-Chad divides as far as Dar Fertit ; on the east by the western boundary of East Africa as far as the northern end of Lake Rudolf, thereafter by a line from Lake Rudolf to the River Sobat; on the north by the Sobat and the Bahr-el-Arab. This region includes the catchment area of the Upper Nile as far as Sobat with the massifs of Ruwenzori, Kilimanjaro, Elgon, and Kenia.

X. North-East Africa. Limited on the west by North Africa, the Sahara, and North Central Africa ; on the south by East Central and East Africa. The region includes Egypt, Nubia, the Eastern Sudan, Abyssinia, and Somaliland, with Yemen and Socotra.

In the first three regions, North Africa, the Sahara, and North Central Africa, no species of Erythrococca has yet been met with; nor has any species been found in the western, or Cape, subdivision of South-East Africa. In all the other regions species of Erythrococca occur in numbers varying from nineteen in West Africa to one in North-East Africa.

Of the nineteen species which occur in West Africa eleven are found in Upper Guinea and nine are endemic there; nine are met with in Lower Guinea and six of these are endemic. Only one of the nineteen is found both in Upper and in Lower Guinea; this species extends across West Central Africa as far as Uganda in East Central Africa. One species is common to Upper Guinea and West Central Africa ; two others are common to Lower Guinea and West Central Africa; yet another extends from Upper Guinea only across West Central to East Central Africa.

In West Central Africa there are nine species only; four of these are endemic. Of the remaining five, three extend to West Africa only; the other two extend both to West Africa and to East Central Africa.

In South-West Africa there are only two species, one of them being endemic and local; the other, which is very widely spread in the region, extends from German South-West Africa and Bechuanaland to Northern Rhodesia and German East Africa. 
In South-East Africa there are, again, only two species; both are confined to the Eastern, or Natal, sub-region, and both are endemic.

In East Africa there are only five species; all of them, however, are endemic. One is confined to the southern or Mozambique sub-region; three are confined to the northern or 'Zanzibaria' sub-region; the fifth, which appears to be a purely littoral species, extends along the Indian Ocean seaboard from Beira in the south to Mombasa in the north.

In East Central Africa there are twelve species, nine of which are endemic; of the others, one is manifestly a South-West African overflow, the remaining two are clearly overflows from West Central Africa.

The solitary North-East African species is endemic, but occurs on both sides of the Red Sea, in Abyssinia and in Yemen.

The sub-genus Euerythrococca, with twenty-five species, is represented in every region where the genus occurs, but most fully so in East Central Africa, where there are nine species ; eight of these are endemic, the ninth is an overflow from South-West Africa. In West Africa this subgenus is rather poorly represented, there being only four species, two in Upper and two in Lower Guinea; all four, however, are endemic. The subgenus Athroandra, on the other hand, though it extends through West Central to East Central Africa, is mainly West African, all but two of the seventeen species which it includes occurring there, and all but four of those that do occur there being endemic. Of the two which are not reported from West Africa, one is endemic in West Central Africa, the other has so far been met with just within the western border of East Central Africa, and, like the two remaining Athroandras in that region, may prove to be only an overflow into the portion of this area which has, as Engler remarks (Pflanzenw. Afr., i.t. 2), a flora of decidedly West African character.

The section Adenoclaoxylon is confined to East Africa, where there are two endemic species, and to East Central Africa, where there are five species, all.endemic. The section Deflersia is more widely spread and extends from Yemen and Abyssinia to Natal, with a very distinctive outlying group of three nearly allied species in West Central Africa, and a solitary, but also very distinctive species in Upper Guinea. One species is endemic in North-East Africa, two are endemic in East Africa, and two in South-East Africa. The section is unrepresented in East Central Africa or in South-West Africa, and there is no species in Lower Guinea. The section Trichogyne may almost be said to occupy the area left vacant by Deflersia. There is no species in North-East Africa, East Africa, or SouthEast Africa, there is no species in West Central Africa, and the solitary species in Upper Guinea occurs just within the south-eastern margin of that sub-region. In East Central Africa Trichogyne is represented by four species, of which three are endemic, the fourth being an overflow from SouthWest Africa, where it is widely spread. In South-West Africa there is 
a second species, local and endemic, near the southern border of Lower Guinea, in which area there is another endemic species. The section Pseudathroandra has only two species, one of them endemic in Lower Guinea, the other in the 'Zanzibaria' sub-region of East Africa.

The section Hemierythrococca is confined to West Africa; its three species are all endemic in Upper Guinea. 'The section Chloropataie has eleven species in West Africa; three of these are endemic in Upper and three in Lower Guinea. There is only one species common to both the Guineas, and this, which extends as far as East Central Africa, may be only an overflow from West Central Africa. Another species extends equally far to the East from Upper Guinea only; one more from Upper Guinea and two others from Lower Guinea extend into West Central Africa. Of the six species of Chloropatane, one of them with a very distinct variety, which occur in West Central Africa, one, and the variety in question, are endemic; the remaining five are distributed, two to Lower Guinea only, one to Upper Guinea only, the other two to East Central Africa on the one hand, to West Africa on the other. In East Central Africa there are but three species of Chloropatane, and only one of these, so far as is known, is endemic.

The distribution of the genus Micrococca is interesting, but presents no feature of difficulty. The only annual species, M. Mercurialis, is a widespread tropical weed in the Eastern Hemisphere. In Africa it is common in cultivated ground in West Africa, both in Upper and in Lower Guinea ; it occurs both in West Central and in East Central Africa; it has been reported in East Africa, both from the Mozambique and the Zanzibaria subdivisions. It appears to be common also in North-East Africa, and extends thence to Southern Arabia. It has been met with in Madagascar. In Asia it is widely spread in Western, Northern, and Southern India, extends thence to Burma and the Malay Peninsula, and is common in Ceylon. The shrubby species have much more restricted ranges. One species, $M$. capensis, is confined to the eastern, or Natal, subdivision of South-East Africa, but is widely spread there from Pondoland to Delagoa Bay. Two species, $M$. Volkensii and $M$. Holstii, seem confined to the Zanzibaria subdivision of East Africa. One species, $M$. Humblotiana, is endemic in the Comoro Group; two, M. Wightii, with its distinct variety hirsuta, and $M$. Beddomei, are endemic in the Malabaria subdivision of India ; the last species, M. oligandra, is endemic in Ceylon.

The subjoined tables show the details of this distribution more compactly. 
I. Conspectus of the Distribution of Erythrococca.

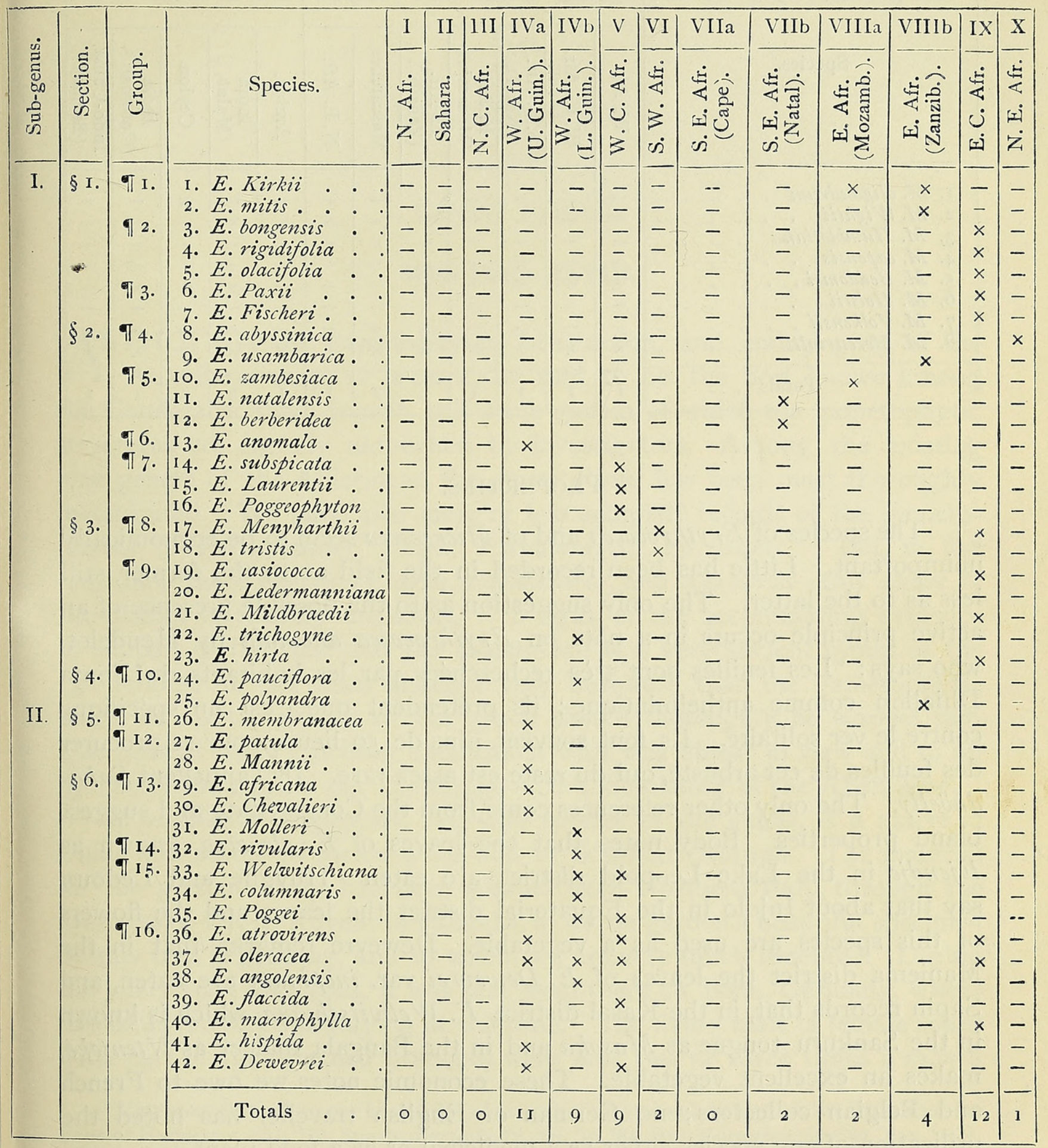


II. Conspectus of the Distribution of Micrococca.

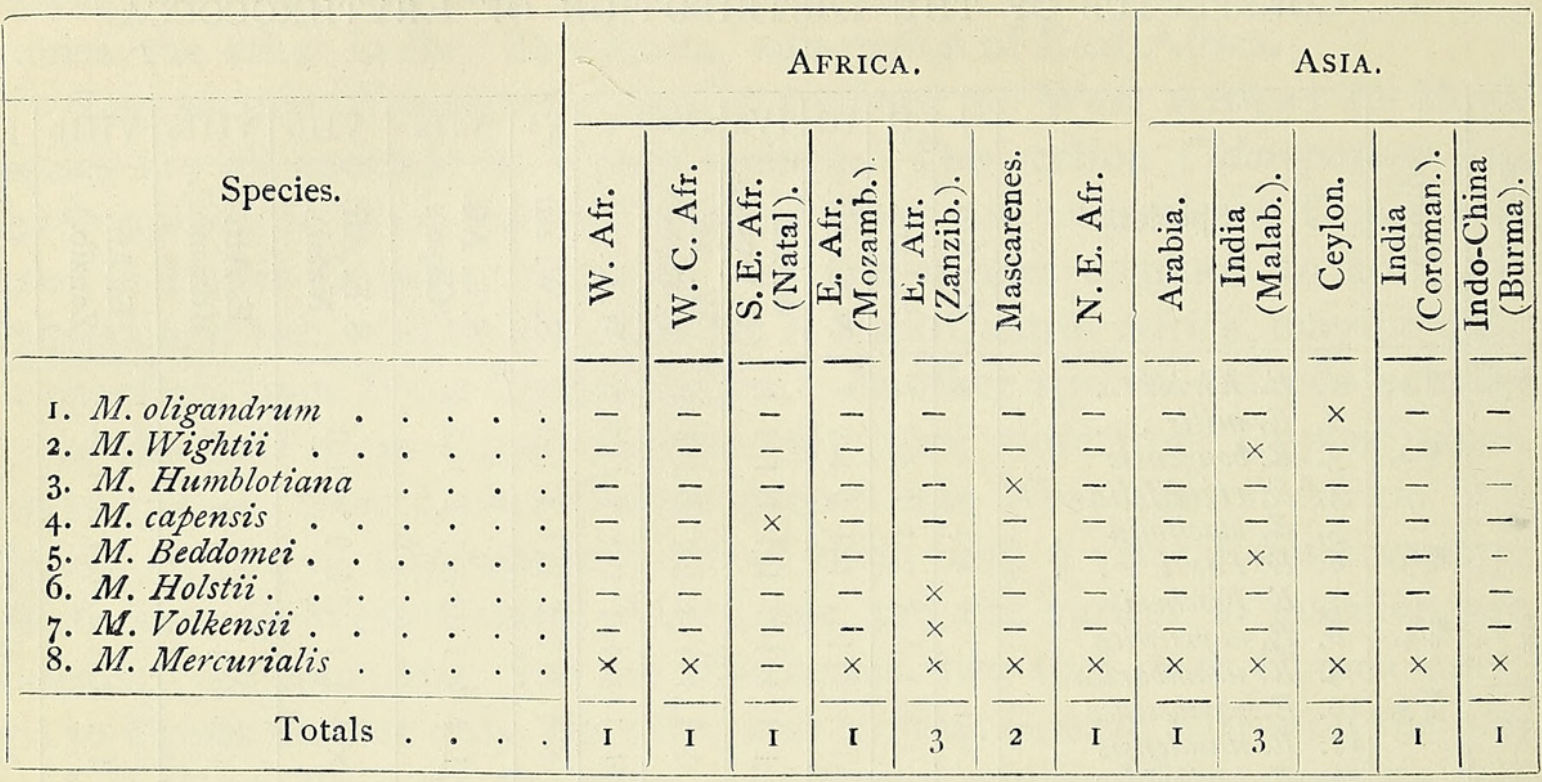

\section{PROPERTIES.}

The species of Erythrococca and of Micrococca seem to be economically unimportant. Little has been recorded in the field as to the former, still less as to the latter. The only suggestion as to the possible presence of an active principle occurs in a note on Erythrococca anomala by Heudelot, who says: 'Les feuilles sont très recherchées par les habitants du Fouta Dhiallon comme anthelmintique; ils prétendent que c'est un spécifique contre le ver solitaire. Ils font souvent plus de 50 lieues pour se procurer des feuilles de cet arbuste, qui du reste est assez rare. Ils l'appellent Sakadhöelly.' The only other references come from the Congo State and suggest bland properties. Body notes that the leaves of $E$. oleracea, known as Ejendje in the Lake Leopold district, are eaten. Huyghe and Ledoux say that about Injolo in the Equatorial district the leaves and the flowers of this species are used as a vegetable. Dewevre remarks that in the Maniema district the leaves of $E$. Dewevrei var. inopinata are eaten, and Sapin records that, in the Kasai district, E. Welwitschiana, which is known in the Sankuru tongue as Masoha and in the Bangala dialect as Ntenteke, makes an excellent vegetable. These economic notes we owe to French and Belgian collectors; no German or English traveller has noted the utilization of any species either as a medicinal or as a food plant. 


\section{$2 \mathrm{BHL}$ Biodiversity Heritage Library}

Prain, D. 1911. "A review of the genera Erythrococca and Micrococca." Annals of botany 25, 575-638. https://doi.org/10.1093/oxfordjournals.aob.a089344.

View This Item Online: https://www.biodiversitylibrary.org/item/239487

DOI: https://doi.org/10.1093/oxfordjournals.aob.a089344

Permalink: https://www.biodiversitylibrary.org/partpdf/319852

\section{Holding Institution}

Smithsonian Libraries

\section{Sponsored by}

Biodiversity Heritage Library

\section{Copyright \& Reuse}

Copyright Status: Not in copyright. The BHL knows of no copyright restrictions on this item.

This document was created from content at the Biodiversity Heritage Library, the world's largest open access digital library for biodiversity literature and archives. Visit BHL at https://www.biodiversitylibrary.org. 